\title{
Measurement and Analysis Infrastructure Diagnostic, Version 1.0: Method Definition Document
}

Mark Kasunic

August 2010

TECHNICAL REPORT

CMU/SEI-2010-TR-035

ESC-TR-2010-035

Software Engineering Measurement and Analysis Unlimited distribution subject to the copyright.

http://www.sei.cmu.edu 
This report was prepared for the

SEI Administrative Agent

$\mathrm{ESC} / \mathrm{XPK}$

5 Eglin Street

Hanscom AFB, MA 01731-2100

The ideas and findings in this report should not be construed as an official DoD position. It is published in the interest of scientific and technical information exchange.

This work is sponsored by the U.S. Department of Defense. The Software Engineering Institute is a federally funded research and development center sponsored by the U.S. Department of Defense.

Copyright 2009 Carnegie Mellon University.

\section{NO WARRANTY}

THIS CARNEGIE MELLON UNIVERSITY AND SOFTWARE ENGINEERING INSTITUTE MATERIAL IS FURNISHED ON AN "AS-IS" BASIS. CARNEGIE MELLON UNIVERSITY MAKES NO WARRANTIES OF ANY KIND, EITHER EXPRESSED OR IMPLIED, AS TO ANY MATTER INCLUDING, BUT NOT LIMITED TO, WARRANTY OF FITNESS FOR PURPOSE OR MERCHANTABILITY, EXCLUSIVITY, OR RESULTS OBTAINED FROM USE OF THE MATERIAL. CARNEGIE MELLON UNIVERSITY DOES NOT MAKE ANY WARRANTY OF ANY KIND WITH RESPECT TO FREEDOM FROM PATENT, TRADEMARK, OR COPYRIGHT INFRINGEMENT.

Use of any trademarks in this report is not intended in any way to infringe on the rights of the trademark holder. Internal use. Permission to reproduce this document and to prepare derivative works from this document for internal use is granted, provided the copyright and "No Warranty" statements are included with all reproductions and derivative works.

External use. This document may be reproduced in its entirety, without modification, and freely distributed in written or electronic form without requesting formal permission. Permission is required for any other external and/or commercial use. Requests for permission should be directed to the Software Engineering Institute at permission@sei.cmu.edu.

This work was created in the performance of Federal Government Contract Number FA8721-05-C-0003 with Carnegie Mellon University for the operation of the Software Engineering Institute, a federally funded research and development center. The Government of the United States has a royalty-free government-purpose license to use, duplicate, or disclose the work, in whole or in part and in any manner, and to have or permit others to do so, for government purposes pursuant to the copyright license under the clause at 252.227-7013. 


\section{Table of Contents}

Abstract iii

$\begin{array}{ll}\text { About This Document } & 1\end{array}$

$\begin{array}{lr}\text { Method Overview } & 5\end{array}$

$1 \quad$ Collaborative Planning $\quad 13$

1.1 Establish Scope 14

1.2 Establish Roles and Expectations $\quad 21$

1.3 Develop Plan and Schedule 24

2 Artifact Evaluation 31

2.1 Prepare for Artifact Evaluation 32

2.2 Conduct M \& A Artifact Evaluation 33

2.3 Perform Quality Audit of Results 37

2.4 Prepare for On-Site Evaluation 38

$3 \quad$ On-Site Evaluation $\quad 49$

3.1 Conduct Orientation Meeting 50

3.2 Conduct Examinations of M \& A Data Repositories 52

3.3 Conduct Interviews 53

$4 \quad$ Report Results $\quad 55$

4.1 Analyze On-Site Evaluation Results 56

4.2 Derive Key Findings $\quad 57$

$\begin{array}{ll}4.3 \text { Deliver Key Findings } & 59\end{array}$

$\begin{array}{ll}\text { 4.4 Plan Next Steps } & 61\end{array}$

Appendix A: MAID Summary 63

Appendix B: Example Agenda for On-Site Evaluation 69

Appendix C: Example Questions for Self-Administered Questionnaire $\quad 71$

Appendix D: Guidance for Conducting Interviews $\quad 77$ 
ii | CMU/SEI-2010-TR-035 


\section{Abstract}

This document is a guidebook for conducting a Measurement and Analysis Infrastructure Diagnostic (MAID) evaluation. The MAID method is a criterion-based evaluation method that is used to assess the quality of an organization's data and the information generated from that data.

The method is organized into four phases: (1) Collaborative Planning, (2) Artifact Evaluation, (3) On-site Evaluation, and (4) Report Results. Using the MAID evaluation criteria as a guide, a MAID team systematically studies and evaluates an organization's measurement and analysis practices by examining the organization's data and observing how the data is manipulated during its lifecycle, from the collection of base measures to the information provided to decision makers.

The outcome of a MAID evaluation is a detailed report of an organization's strengths and weaknesses in measurement and analysis. 
iv | CMU/SEI-2010-TR-035 


\section{About This Document}

Introduction

Intended audience

How this document is organized
This section describes this document and how it is organized.

Intended readers include all people who will be involved in a Measurement and Analysis Diagnosis (MAID) effort. This includes those conducting the MAID evaluation and personnel from the organization undergoing the evaluation.

This document begins with a Method Overview section that provides an introduction to the MAID method. This overview is followed by the method description.

The method description is hierarchically organized in the following way:

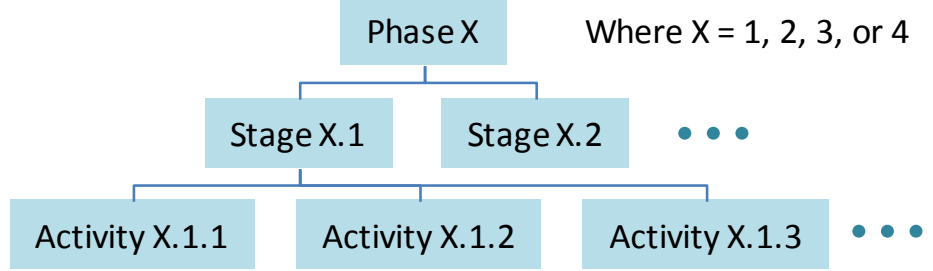

MAID is composed of four phases:

1. Collaborative Planning

2. Artifact Evaluation

3. On-site Evaluation

4. Report Results

The phase description provides an overview of the activities within that phase.

The stage description is a breakdown of a phase. In some cases a stage is further decomposed into activity descriptions, and the stage description serves as an overview of the activity descriptions. In other cases, further decomposition is unnecessary and the stage is described in the same way as an activity.

The activity description is typically elucidated by the components listed in the next table. 


\section{How this document is organized, cont.}

\begin{tabular}{|c|c|}
\hline Component & Explanation \\
\hline $\begin{array}{l}\text { Activity } \\
\text { Description }\end{array}$ & Provides an overview of the activity. \\
\hline $\begin{array}{l}\text { Who } \\
\text { participates? }\end{array}$ & $\begin{array}{l}\text { The roles that need to be filled for the MAID } \\
\text { activity. The individuals in these roles are } \\
\text { responsible for ensuring that the activity is } \\
\text { performed. However, in many cases, it is } \\
\text { acceptable if the performance is delegated to } \\
\text { an associate. }\end{array}$ \\
\hline $\begin{array}{l}\text { Information } \\
\text { needed }\end{array}$ & $\begin{array}{l}\text { Information that is required to conduct the } \\
\text { activity. In many cases, the information needed } \\
\text { is a product from a previous MAID activity. } \\
\text { When this is the case, the listed item is } \\
\text { followed by the phase/stage/activity number in } \\
\text { square brackets (i.e., [\#.\#.\#]). }\end{array}$ \\
\hline Procedure & $\begin{array}{l}\text { A concise step-by-step description of what } \\
\text { happens and who does it. }\end{array}$ \\
\hline Products & The products that are created by the activity. \\
\hline $\begin{array}{l}\text { Additional } \\
\text { guidance }\end{array}$ & $\begin{array}{l}\text { Additional heuristics and/or tips for conducting } \\
\text { the activity. }\end{array}$ \\
\hline
\end{tabular}

The method description is followed by the appendices and a brief reference section.

Appendix A provides a summary of MAID, showing the information needed and products produced by each stage or activity. 
Related

documents

How you can

provide feedback
A companion document describes the evaluation criteria that are used during a MAID. This document is referred to often within the MAID method:

Measurement and Analysis Infrastructure Diagnostic (MAID) Evaluation Criteria, Version 1.0 [SEMA 2009]

The following document describes the motivation and rationale for MAID:

Can You Trust Your Data? Establishing the Need for a Measurement and Analysis Infrastructure Diagnostic [Kasunic 2008]

We are interested in your ideas for improving the MAID method and its application. If you have suggestions or questions, please send email to info@sei.cmu.edu. 
4 | CMU/SEI-2010-TR-035 


\section{Method Overview}

Introduction

What is the MAID method?
How reliable is the data that organizations collect and use? How useful and effective is the information that is generated from that data?

Given the importance of measurement and analysis in decision making, organizations need to ensure their data, analyses, and corresponding reports are of high quality and meet the information needs of practitioners and managers. Yet, organizations often have no method for evaluating the quality of their measurement and analysis infrastructure and have very little trust in their own data.

Ensuring information quality is a challenge for most organizationspartly because they may not be fully aware of their own data quality levels. Without this information, they cannot know the full business impact of poor or unknown data quality or how to begin addressing it.

The Measurement and Analysis Infrastructure Diagnostic (MAID) method is a criterion-based evaluation method that assesses the quality of an organization's data and the information generated from that data. The method is organized into four phases, as illustrated in Figure 1.

\section{Collaborative planning \\ 2. Artifact evaluation \\ 3. On-site evaluation \\ 4. Report \\ results}

Figure 1: The MAID Method 
The MAID context
Using the MAID evaluation criteria as a guide, a MAID team systematically studies and evaluates an organization's measurement and analysis practices by examining the organization's data and observing how the data is manipulated during its lifecycle, from the collection of base measures to the information provided to decision makers. (See Figure 2.)

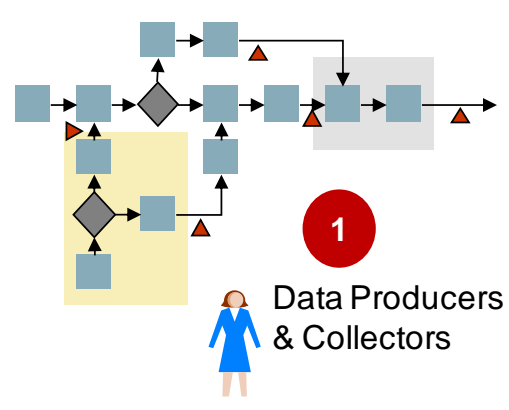

2

Data Managers

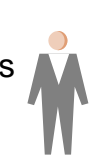

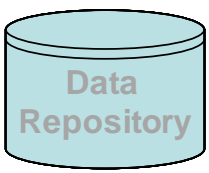

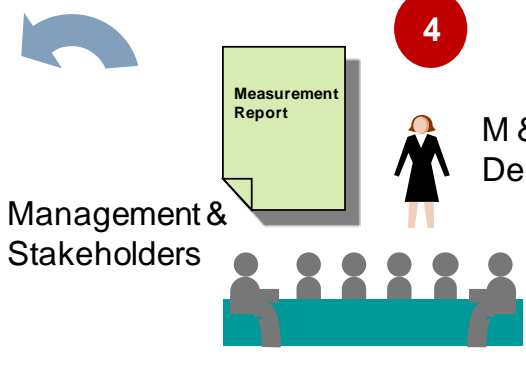

3 Measurement Analysts

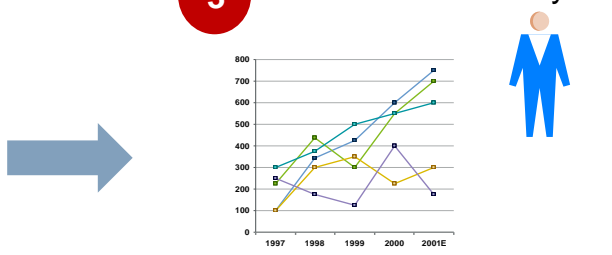

$\Delta$ Measurements collected

Figure 2: Measurement Information Stream From Its Source

MAID objectives
A MAID evaluation is conducted to meet two objectives:

1. Evaluate data quality and compare an organization's current measurement and analysis practices against a defined set of criteria that are based on best practices.

With respect to this objective, some of the questions that the organization needs to answer include the following:

- Are we doing the right things in terms of measurement and analysis?

- Are information needs being met? How well?

- How good is our data?

- How well does the information we generate support effective decision making?

- What kind of value is our measurement program really providing to the organization and its stakeholders?

Continued on next page 
MAID objectives, Continued

MAID is a collaboration
2. Make recommendations for improvement.

Questions that are addressed through this objective include the following:

- Are there hidden quality issues that are affecting the accuracy and reliability of measurement information reported to decision makers?

- Are there opportunities to improve the quality of the $M$ \& $A$ information? What are they?

- How can identified gaps or weaknesses be addressed?

- Are there opportunities to improve the quality of the M\&A information? What are they?

- What M \& A practices are "best practices" and should be encouraged across the organization?

How can we prepare for achieving higher process maturity?

A MAID evaluation is conducted through a collaboration between an evaluation team and members of the client organization that has requested a MAID (see Figure 3).

Although the MAID team interacts directly with many individuals from the client organization, much of the communication-especially during the first two phases of MAID—is facilitated by the client point of contact (POC).

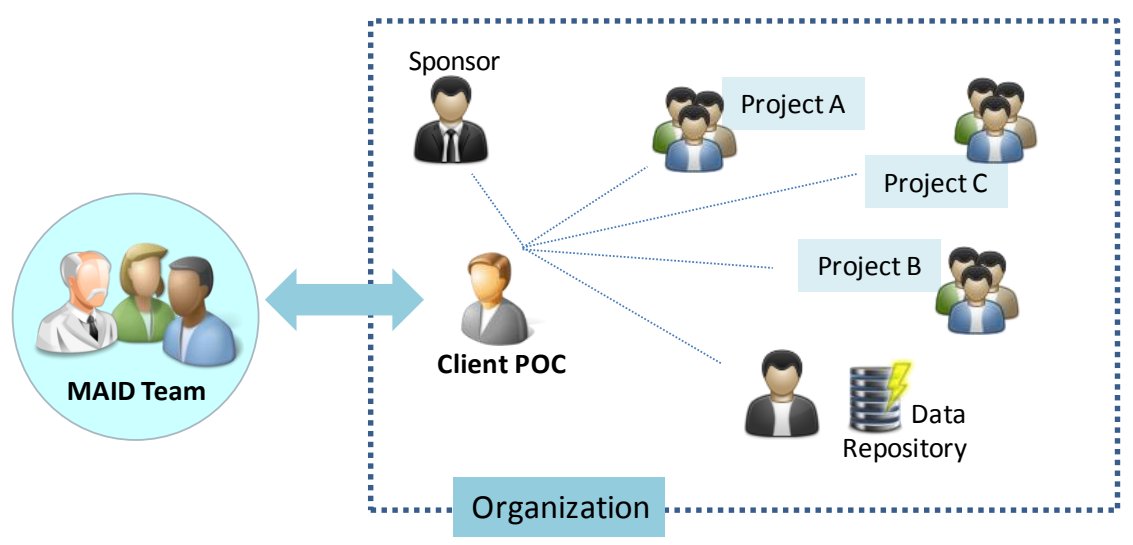

Figure 3: MAID Team Collaborates With Organization to Produce Result 

evaluation.

\begin{tabular}{|c|c|}
\hline Role & Description \\
\hline Team lead & $\begin{array}{l}\text { - leader of the evaluation team } \\
\text { - } M \text { \& A expert } \\
\text { - } \text { point of contact (POC) for communication } \\
\text { between client and MAID evaluation team } \\
\text { - } \text { responsible for all administrative and } \\
\text { organization activities associated with a MAID }\end{array}$ \\
\hline Team members & $\begin{array}{l}\text { - M \& A experts who participate as MAID } \\
\text { evaluators } \\
\text { - } \text { participate in MAID activities based on needs } \\
\text { expressed by the MAID team lead }\end{array}$ \\
\hline Sponsor & $\begin{array}{l}\text { - senior client manager who has authorized the } \\
\text { MAID evaluation } \\
\text { - participates in MAID planning and is the } \\
\text { recipient of the MAID results }\end{array}$ \\
\hline Client POC & $\begin{array}{l}\text { - POC for communication between the client } \\
\text { organization and the MAID team lead } \\
\text { - coordinates planning and scheduling of MAID } \\
\text { activities for the client organization } \\
\text { - facilitates delivery of M \& A artifacts to the } \\
\text { team lead } \\
\text { - orchestrates all activities to facilitate the } \\
\text { conduct of MAID at the client's site }\end{array}$ \\
\hline Client SME & $\begin{array}{l}\text { - client M \& A subject matter experts (SMEs) } \\
\text { who are knowledgeable about the M \& A } \\
\text { activities, tools, and work products that are } \\
\text { within the defined MAID scope } \\
\text { - answers questions about the M \& A } \\
\text { documentation submitted as part of the MAID } \\
\text { scope } \\
\text { - } \text { participates in MAID interviews }\end{array}$ \\
\hline $\begin{array}{l}\text { Questionnaire } \\
\text { respondents }\end{array}$ & $\begin{array}{l}\text { - respond to questions or questionnaires that } \\
\text { are included as part of the MAID scope }\end{array}$ \\
\hline Stakeholders & $\begin{array}{l}\text { - client individuals who are interested in the } \\
\text { results of a MAID evaluation }\end{array}$ \\
\hline
\end{tabular}


MAID evaluation team

Team composition and skill set
The MAID evaluation team can be composed of (a) individuals from the client organization if the individuals possess $M$ \& $A$ expertise, (b) external $M \& A$ experts who are contracted by the organization to perform the MAID evaluation, or (c) a combination of $a$ and $b$.

Conducting a MAID evaluation involves making judgments about aspects of $M \& A$ that include (but are not limited to)

- measurement definition approaches

- data quality attributes

- data storage and access mechanisms

- $M \&$ A processes and procedures

- data analysis techniques

- $M \& A$ information design

Therefore, it is important that the MAID evaluation team is composed of individuals with the knowledge and skills needed to make these judgments.

Team members should also possess

- organizational skills (to perform a significant amount of planning, document handling, and record-keeping)

- interviewing and effective listening skills

- effective writing skills

Phase 2: Artifact Evaluation involves conducting interviews. Having a team member who is effective at recording the interviews is essential. 
MAID evaluation criteria
The MAID method uses a set of criteria that draws upon, synthesizes, and organizes well-established best $\mathrm{M} \& \mathrm{~A}$ practice guidance that is already embodied in existing models, standards, methods, and applicable best practices.

The MAID criteria were published in Measurement and Analysis Infrastructure Diagnostic (MAID) Evaluation Criteria, Version 1.0 [SEMA 2009]. The criteria are organized into five categories, described in Table 1.

Table 1: $\quad$ Major topics covered in each category of MAID criteria

\begin{tabular}{|c|c|}
\hline Criteria Categories & Major Topics \\
\hline M \& A Planning & $\begin{array}{l}\text { - Identifying } M \text { \& A resource needs and training needs } \\
\text { - Identifying M \& A information needs } \\
\text { - Identifying and defining measures and measurement } \\
\text { indicators that address needs } \\
\text { - } \quad \text { Planning and scheduling } M \& A \text { activities } \\
\text { - Developing } M \& A \text { processes and procedures to perform } \\
\text { M \& A activities }\end{array}$ \\
\hline $\begin{array}{l}\text { Data Collection and } \\
\text { Storage }\end{array}$ & $\begin{array}{l}\text { - } \quad \text { Collecting M \& A data that address information needs } \\
\text { - } \quad \text { Ensuring completeness and accuracy of the recorded data } \\
\text { - } \quad \text { Ensuring that data are stored securely }\end{array}$ \\
\hline Data Analysis & $\begin{array}{l}\text { - Preparing the data for analysis } \\
\text { - Transforming the data into tables and graphs that can be } \\
\text { analyzed } \\
\text { - Selecting the appropriate statistical analysis approach to } \\
\text { analyze the data } \\
\text { - Conducting statistical analyses of the data }\end{array}$ \\
\hline M \& A Reporting & $\begin{array}{l}\text { - Understanding the M \& A expertise level of the stakeholders } \\
\text { who will use the M \& A information to support decision } \\
\text { making } \\
\text { - Transforming the data analysis results into M \& A } \\
\text { information that best facilitates comprehension by the } \\
\text { stakeholders who will use the information to support } \\
\text { decision making }\end{array}$ \\
\hline $\begin{array}{l}\text { Criteria for All M \& A } \\
\text { Process or Procedure } \\
\text { Documentation }\end{array}$ & - Writing effective $M$ \& A documentation \\
\hline
\end{tabular}


MAID recordkeeping

MAID is tailored to meet needs
Accurate recordkeeping is a critical facet of the MAID method. Each MAID criterion is rated and rationale is provided for each rating.

References to artifacts, interviews, and observations are documented to ensure traceability to the source of any findings.

Organizing the criteria into a spreadsheet with additional columns reserved for ratings, references, and other comments provides a simple software support tool to assist the evaluation team. ${ }^{1}$

MAID is not a one-size-fits-all method. The approach is highly tailorable based on the specific objectives of the client organization that has requested a MAID evaluation.

An organization may choose to select a large scope (e.g., one that encompasses multiple projects including measurement roll-up for reporting to the executive level) or a smaller scope that addresses only one or two projects.

MAID can address the entire $M \& A$ life cycle (Planning, Data Collection and Storage, Data Analysis, and M \& A Reporting). However, an organization may choose to focus on one or several of these phases of the life cycle.

Other tailoring options are available at the discretion of the client organization.

The need for communication is not always spelled out in MAID activities. However, effective communication is critical to the MAID method.

The MAID team leader and client POC must ensure that all stakeholders are kept informed throughout the execution of MAID.

The SEI is collaborating with the Universidad Carlos III de Madrid to develop a web-based software support tool for MAID. 
12 | CMU/SEI-2010-TR-035 


\section{$1 \quad$ Collaborative Planning}

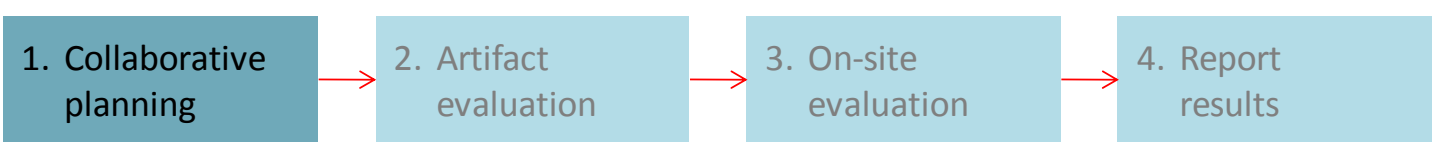

Introduction During Phase 1: Collaborative Planning, the MAID team and the client organization plan and prepare for the MAID.

The evaluation team leader collects information from the organization's sponsor to ensure that MAID objectives align with and support the business goals of the organization.

Before you

Before beginning this phase, the organization sponsor should be able begin to describe the organization's business needs and how a MAID evaluation will address those needs.

Stages

The stages included in this phase are

\subsection{Establish Scope}

1.2 Establish Roles and Expectations

1.3 Develop Plan and Schedule 


\subsection{Establish Scope}

\section{Overview}

Activities during this stage

Tradeoffs are involved
During this stage the sponsor works with the MAID team leader to identify the specific areas to focus on during the evaluation. To accomplish this, the sponsor must take into account

- the prioritized business needs of the organization

- the objectives for the MAID evaluation

- cost and time constraints

The objectives that motivate a MAID intervention must be well understood and balanced with the constraints so that the appropriate participants, tailoring decisions, and MAID outputs can be determined.

This stage is composed of the following activities:

\subsubsection{Determine MAID Objectives}

1.1.2 Determine Constraints

1.1.3 Determine the MAID Scope

The intention is to find the right balance between objectives and constraints. It is sometimes necessary to iterate between activities 1.1.1 (Determine MAID Objectives) and 1.1.2 (Determine Constraints) in order to achieve 1.1.3 (Determine the MAID Scope).

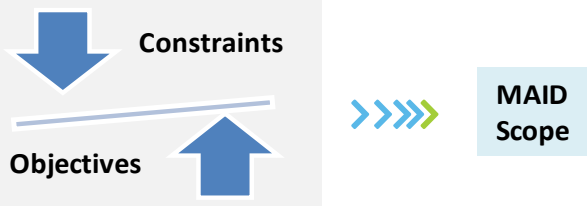

Figure 4: Balancing objectives and constraints 


\subsubsection{Determine MAID Objectives}

\author{
Activity \\ description
}

Examples of MAID objectives
Who

participates?

Information

needed

\section{Procedure}

The purpose of this activity is to develop a shared understanding of the MAID objectives among the organization sponsors, MAID evaluation team, and all other MAID participants.

The business needs of the organization drive the requirements for a MAID evaluation. An organization conducts the evaluation to

- understand the degree of data and M \& A information quality of the organization

- identify risk areas within its $M \& A$ program

- improve its M \& A practices in a project, set of projects, or across an entire organization

- benchmark its $M \& A$ practices across the organization

- benchmark its M \& A practices with other organizations

- obtain guidance for expanding or evolving its $M \& A$ program

- Sponsor

- Team lead

Description of the organization's business goals or business needs

\begin{tabular}{|l|l|l|}
\hline Step & Who? & What happens? \\
\hline 1 & Team lead & Identifies sponsor and other stakeholders. \\
\hline 2 & Team lead & Establishes communication with sponsor. \\
\hline 3 & $\begin{array}{l}\text { Team lead, } \\
\text { Sponsor }\end{array}$ & $\begin{array}{l}\text { Team lead documents the business goals } \\
\text { and the MAID objectives provided by the } \\
\text { sponsor. }\end{array}$ \\
\hline 4 & $\begin{array}{l}\text { Team lead, } \\
\text { Sponsor }\end{array}$ & $\begin{array}{l}\text { Verifies alignment of MAID objectives with } \\
\text { business goals. }\end{array}$ \\
\hline
\end{tabular}


Products

Additional

Guidance

- In some cases, the sponsor will have a representative (such as the client POC) work on the details of the initial planning. This is acceptable as long as the sponsor is kept informed of those details along the way and buys into the agreements that are negotiated and documented.

- The sponsor must acknowledge his or her agreement with the MAID objectives. One way to do so is to sign the documented objectives. 


\subsubsection{Determine Constraints}

\section{Activity description}

Who

participates?

Information

needed

Procedure
The constraints under which a MAID evaluation is conducted are typically posed by such factors as

- cost

- schedule

- personnel availability

During this activity, the sponsor and the evaluation team lead discuss the constraints and how this may limit the scope of the evaluation.

- Sponsor

- Team lead

- $\quad$ List of MAID objectives [1.1.1]

- Estimates of personnel availability

The table below describes key tasks of this activity.

\begin{tabular}{|l|l|l|}
\hline Step & Who? & What happens? \\
\hline 1 & Sponsor, Team lead & $\begin{array}{l}\text { Establish high-level cost and schedule } \\
\text { constraints. }\end{array}$ \\
\hline 2 & Sponsor, Team lead & $\begin{array}{l}\text { Determine which organizational entities } \\
\text { are candidates for inclusion in the } \\
\text { MAID evaluation. }\end{array}$ \\
\hline 3 & Sponsor, Team lead & $\begin{array}{l}\text { Negotiate constraints and objectives to } \\
\text { ensure feasibility. }\end{array}$ \\
\hline 4 & Team lead & $\begin{array}{l}\text { Documents negotiated constraints to } \\
\text { be met and revisions to the original } \\
\text { objectives based on the results of this } \\
\text { activity. }\end{array}$ \\
\hline
\end{tabular}


Products

- List of constraints to be met (accompanied by rationale for decisions made)

- List of personnel availability

- List of revised MAID objectives (based on the results of this activity)

18 | CMU/SEI-2010-TR-035 


\subsubsection{Determine MAID Scope}

\section{Activity description}

Who
participates?

Information

needed
The MAID scope consists of two parts: (1) the scope based on categories of MAID evaluation criteria that will be used and (2) the organizational scope.

Five categories of evaluation criteria can be used during a MAID evaluation:

1. $M \&$ A Planning

2. Data Collection and Storage

3. Data Analysis

4. $M \&$ A Reporting

5. $M \& A-$ General

In some cases, the client may want only a subset of these categories to be evaluated instead of all five. This is especially likely in organizations that are just starting their M \& A programs; these organizations may want to limit the scope to an evaluation of their $M$ \& A planning progress. A decision about which categories to include should be made based on the objectives and constraints.

The organizational scope refers to the identification of the organizational entities that will be included as part of the MAID evaluation. A full organizational scope would include the organization and all projects within the organization. A partial scope would include a subset of the full organizational scope.

- Sponsor

- Team lead

- $\quad$ List of revised MAID objectives [1.1.2]

- List of constraints to be me [1.1.2] 
The table below describes the key tasks of this activity.

\begin{tabular}{|l|l|l|}
\hline Step & Who? & What happens? \\
\hline 1 & Sponsor, Team lead & $\begin{array}{l}\text { Selects the organizational entities that } \\
\text { will be included in the MAID evaluation. }\end{array}$ \\
\hline 2 & Sponsor, Team lead & $\begin{array}{l}\text { For each entity selected in step 1, } \\
\text { selects the MAID criteria categories } \\
\text { that will be used to evaluate each } \\
\text { entity. }\end{array}$ \\
\hline 3 & Team lead & $\begin{array}{l}\text { Documents the results of steps 1 and 2 } \\
\text { and provides rationale for the decision. }\end{array}$ \\
\hline
\end{tabular}

Products

MAID scope statement that includes

- identification of organizational entities that will be included in the MAID evaluation

- identification of MAID criteria categories that will be used for each organizational entity

- rationale for decisions made

Additional guidance
The scope identified during this early stage of MAID is expected to be high level and not very detailed. During subsequent planning, the scope may be modified. For example, it might change after detailed estimates are made about the effort involved in carrying out the MAID evaluation. 


\subsection{Establish Roles and Expectations}

Overview

Key roles
Once the scope for the MAID evaluation is established, the appropriate personnel are identified and enlisted to participate in the effort. This includes members of the evaluation team and individuals from the client organization undergoing the evaluation.

This table lists the key roles that need to be filled during a MAID evaluation.

\begin{tabular}{|c|c|}
\hline Role & Description \\
\hline Team lead & $\begin{array}{l}\text { - } \\
\text { - } \\
\text { - } \\
\text { M \& A expert } \\
\text { beint of contact (POC) for communication } \\
\text { betwen client and MAID evaluation team } \\
\text { responsible for all administrative and } \\
\text { organization activities associated with a } \\
\text { MAID }\end{array}$ \\
\hline Team members & $\begin{array}{l}\text { - } \quad \text { M \& A experts who participate as MAID } \\
\text { evaluators } \\
\text { - } \quad \text { participate in MAID activities based on needs } \\
\text { expressed by MAID team lead }\end{array}$ \\
\hline Sponsor & $\begin{array}{l}\text { - senior client manager who has authorized } \\
\text { the MAID evaluation } \\
\text { - participates in MAID planning and is the } \\
\text { recipient of the MAID results }\end{array}$ \\
\hline Client POC & $\begin{array}{l}\text { - POC for communication between the client } \\
\text { organization and the MAID team lead } \\
\text { coordinates planning and scheduling of MAID } \\
\text { activities for the client organization } \\
\text { - } \quad \text { facilitates delivery of M \& A artifacts to the } \\
\text { team lead } \\
\text { - } \\
\text { orchestrates all activities to facilitate the } \\
\text { conduct of MAID at the client's site }\end{array}$ \\
\hline
\end{tabular}

Table continues on next page 
Key roles, cont.

\begin{tabular}{|c|c|}
\hline Client SME & $\begin{array}{l}\text { - client M \& A subject matter experts } \\
\text { (SMEs) who are knowledgeable about } \\
\text { the M \& A activities, tools, and work } \\
\text { products that are within the defined } \\
\text { MAID scope } \\
\text { - answers questions about the M \& A } \\
\text { documentation submitted as part of the } \\
\text { MAID scope } \\
\text { - participates in MAID interviews }\end{array}$ \\
\hline $\begin{array}{l}\text { Questionnaire } \\
\text { respondents }\end{array}$ & $\begin{array}{l}\text { - } \text { responds to questions or } \\
\text { questionnaires that are included as } \\
\text { part of the MAID scope }\end{array}$ \\
\hline Stakeholders & $\begin{array}{l}\text { - client individuals who are interested in } \\
\text { the results of a MAID evaluation }\end{array}$ \\
\hline
\end{tabular}

Who

participates?

Procedure

22 | CMU/SEI-2010-TR-035
- Team lead

- Client POC

The table below describes the key tasks of this activity.

\begin{tabular}{|l|l|l|}
\hline Step & Who? & What happens? \\
\hline $1 \mathrm{a}$ & Team lead & $\begin{array}{l}\text { Based on the established scope, determines the } \\
\text { appropriate size of the MAID team. Obtains } \\
\text { additional resources as required. } \\
\text { Records availability information for each team } \\
\text { member (e.g., vacation days, days not available, } \\
\text { \% time available for the MAID evaluation). }\end{array}$ \\
\hline $1 b$ & $\begin{array}{l}\text { Client } \\
\text { POC }\end{array}$ & $\begin{array}{l}\text { Identifies the client SME for each of the areas that } \\
\text { will be evaluated during the MAID evaluation (see } \\
\text { Additional guidance on page 23). }\end{array}$ \\
\hline
\end{tabular}

Table continues on next page 
Procedure, cont.

\begin{tabular}{|l|l|l|}
\hline Step & Who? & What happens? \\
\hline 3 & Client POC & $\begin{array}{l}\text { Communicates with each of the client SMEs } \\
\text { to brief them on their MAID role and how they } \\
\text { will participate in the effort. } \\
\text { Determines if availability will be an issue. } \\
\text { Records availability information for each } \\
\text { SME. } \\
\text { Coordinates SME participation with } \\
\text { management. }\end{array}$ \\
\hline 4 & Client POC & $\begin{array}{l}\text { Develops a List of client SMEs including } \\
\text { organizational role and contact information. } \\
\text { Delivers this list to the team lead. }\end{array}$ \\
\hline
\end{tabular}

\section{Products}

- List of MAID team members with contact information and availability information

- List of client SMEs that includes the following descriptors

- name

- contact information (phone, email)

- organization/project

- organization/project title

- $\quad M \&$ A role in organization

- M \& A SME area designation ${ }^{3}$

- availability information

\section{Additional} guidance

- SMEs are selected based on their knowledge of M \& A planning, procedures, and practices for the organization or for a particular project or role such as a data manager or data analyst. An SME could also be a preparer of measurement information for reports or briefings.

- In some cases, there may be multiple SMEs for a particular area that will undergo MAID evaluation.

3 This is the area in which the individual has expertise or extensive knowledge. The area may be a data repository designation or it could refer to specific M \& A planning or process/procedure areas. 


\subsection{Develop Plan and Schedule}

Overview

Activities during this stage

Additional guidance
During this stage, the MAID team lead works with the client POC to establish a plan and schedule for conducting the MAID evaluation.

The MAID team lead coordinates with the MAID team members to obtain planning/scheduling inputs and constraints while the client POC coordinates with individuals from the organization to obtain inputs that are relevant to planning the MAID evaluation.

This stage comprises the following activities:

1.3.1 Determine MAID Outputs

1.3.2 Determine MAID Inputs

1.3.3 Tailor Method

1.3.4 Determine Cost and Schedule

1.3.5 Obtain Commitment to the Plan

Planning is iterative in nature. Once the baseline plan is documented, additional detail should be added as it becomes available over time. 


\subsubsection{Determine MAID Outputs}

\author{
Activity \\ description
}

Who

participates?

Information

needed

Types of MAID output

Procedure

Products
During this activity, the specific outputs of the MAID evaluation are discussed, negotiated, and agreed upon.

- Client POC

- Team lead

- $\quad$ List of revised MAID objectives [1.1.2]

- Input from sponsor to client POC

The results of a MAID evaluation can be reported in several ways, including one or a combination of the following:

- presentation in slide format of $M \&$ \& strengths and weaknesses

- MAID survey results

- list of MAID criteria with ratings for each criterion and rationale for the rating

- recommendations for addressing $M \& A$ weaknesses

- detailed report that elaborates the MAID findings

The table below describes the key tasks of this activity.

\begin{tabular}{|l|l|l|}
\hline Step & Who? & What happens? \\
\hline 1 & $\begin{array}{l}\text { Client POC, } \\
\text { Team lead }\end{array}$ & $\begin{array}{l}\text { Discuss the various options and the impact of } \\
\text { each on effort and schedule. }\end{array}$ \\
\hline 2 & Client POC & $\begin{array}{l}\text { Solicits preferences from the sponsor } \\
\text { regarding desired reporting content and } \\
\text { format for the MAID results. }\end{array}$ \\
\hline 3 & Client POC & Communicates desired output to team lead. \\
\hline
\end{tabular}

List of outputs with descriptions that will be developed based on the results of the MAID evaluation 


\subsubsection{Determine MAID Inputs}

\author{
Activity \\ description
}

Who

participates?

Information

needed

Procedure

Product

Product description
During this activity, all $\mathrm{M} \& \mathrm{~A}$-related documents, $\mathrm{M} \& \mathrm{~A}$ tools, and data repositories included in the MAID scope are identified and cataloged.

- Client SMEs

- Client POC

- Team lead

List of client SMEs [1.2]

The table below describes the key tasks of this activity.

\begin{tabular}{|l|l|l|}
\hline Step & Who? & What happens? \\
\hline 1 & Client POC & $\begin{array}{l}\text { Contacts client SMEs to have them submit } \\
\text { their input to the M \& A artifact list. }\end{array}$ \\
\hline 2 & Client SMEs & $\begin{array}{l}\text { Provides input to the M \& A artifact list based } \\
\text { on MAID assignment area. }\end{array}$ \\
\hline 3 & Client POC & $\begin{array}{l}\text { Sends the completed } M \text { \& } A \text { artifact inventory } \\
\text { to the team lead. }\end{array}$ \\
\hline
\end{tabular}

$M \& A$ artifact inventory

The $M \& A$ artifact inventory is a list where each record contains the following information:

- name of artifact

- filename of artifact (if applicable)

- type of file (if applicable)

- how the artifact is used in the organization (e.g., M \& A planning, guidance for data collection and storage, a data reporting artifact)

- number of pages (if a document)

- number of records (if a spreadsheet or database)

- name of client SME who is knowledgeable about the artifact 


\subsubsection{Tailor Method}

\author{
Activity \\ description
}

Who

participates?

Information needed

Procedure

Products
The MAID method provides a wide variety of options to allow the client organization to select the features of the method that best address the client's business objectives.

During this activity, the client selects specific implementation options based on objectives and constraints.

- $\quad$ Client POC

- Team lead

- $\quad$ List of revised MAID objectives [1.1.2]

- List of constraints to be met accompanied by rationale for decisions made [1.1.2]

- MAID scope statement [1.1.3]

The table below describes the key tasks of this activity.

\begin{tabular}{|l|l|l|}
\hline Step & Who? & What happens? \\
\hline 1 & Client POC & $\begin{array}{l}\text { Steps through MAID Method Definition } \\
\text { Document (i.e., this document) to } \\
\text { determine candidate activities that } \\
\text { might need to be tailored. }\end{array}$ \\
\hline 2 & $\begin{array}{l}\text { Client POC, Team } \\
\text { lead }\end{array}$ & $\begin{array}{l}\text { Meet to discuss tailoring options and } \\
\text { risks/benefits of pursuing an option. }\end{array}$ \\
\hline 3 & Team lead & $\begin{array}{l}\text { Documents tailoring decisions and } \\
\text { submits them to the client POC for } \\
\text { approval. }\end{array}$ \\
\hline 4 & Client POC & $\begin{array}{l}\text { Reviews tailoring decisions and } \\
\text { approves. }\end{array}$ \\
\hline
\end{tabular}

Approved tailoring decisions 
Additional guidance
Some example areas where the method can be tailored include

- conducting executive sessions

- selecting data collection approaches, such as whether to use a survey or not

- conducting site interviews of small groups vs. individuals

- adjusting the level of rigor applied to data error checking by MAID evaluators

- determining the detail of feedback and recommendations included when reporting MAID results 


\subsubsection{Determine Cost and Schedule}

\author{
Activity \\ description
}

Who

participates?

Information

needed

Procedure

Product

Additional guidance
An initial cost breakdown and schedule are developed for review by the client organization.

- Team lead

- Client POC

- $\quad$ List of revised MAID objectives [1.1.2]

- MAID scope statement [1.1.3]

- Approved tailoring decisions [1.3.3]

The table below describes the key tasks of this activity.

\begin{tabular}{|c|c|c|}
\hline Step & Who? & What happens? \\
\hline 1 & Team lead & $\begin{array}{l}\text { Estimates the duration of MAID } \\
\text { activities as a basis for deriving a } \\
\text { comprehensive schedule. }\end{array}$ \\
\hline 2 & $\begin{array}{l}\text { Team lead, Client } \\
\text { POC }\end{array}$ & Meet to review the results of step 1 . \\
\hline 3 & Team lead & $\begin{array}{l}\text { Estimates the cost for incidentals } \\
\text { associated with conducting the MAID } \\
\text { evaluation (e.g., travel, lodging, meals). }\end{array}$ \\
\hline 4 & Team lead & $\begin{array}{l}\text { Documents the results and sends to } \\
\text { client POC for review and feedback. }\end{array}$ \\
\hline 5 & Client POC & $\begin{array}{l}\text { Reviews cost and schedule estimates } \\
\text { and provides feedback to team lead. }\end{array}$ \\
\hline 5 & Team lead & $\begin{array}{l}\text { If client POC has change requests, } \\
\text { begins again at step } 1 .\end{array}$ \\
\hline
\end{tabular}

Approved cost and schedule estimates for MAID effort

In many organizations, it may be necessary to obtain guidance from one of the organization's financial analysts. 


\subsubsection{Obtain Commitment to the Plan}

\author{
Activity \\ description
}

Who

participates?

Information needed

Procedure

\section{Products}

Approved MAID plan

- Team lead

- Client POC

- Client sponsor

- Client SMEs

- Stakeholders

This activity involves authoring the plan and obtaining formal commitment to the MAID plan from the sponsor.

- $\quad$ List of revised MAID objectives [1.1.2]

- $\quad$ List of personnel availability [1.1.2]

- $\quad$ The following parts of the MAID scope statement [1.1.3]:

- Identification of organizational entities that will be included in the MAID evaluation

- Identification of MAID criteria categories that will be used for each organizational entity

- Approved cost and schedule estimates for MAID effort [1.3.4]

The table below describes the key tasks of this activity.

\begin{tabular}{|l|l|l|}
\hline Step & Who? & What happens? \\
\hline 1 & Team lead & $\begin{array}{l}\text { Compiles the various inputs (information } \\
\text { needed) and documents the MAID plan. }\end{array}$ \\
\hline 2 & Client POC & $\begin{array}{l}\text { Reviews the plan and provides feedback } \\
\text { to the team lead. }\end{array}$ \\
\hline 3 & $\begin{array}{l}\text { Client sponsor, } \\
\text { Client POC, } \\
\text { Team lead }\end{array}$ & $\begin{array}{l}\text { Team lead and client POC review the plan } \\
\text { with sponsor and secure the sponsor's } \\
\text { approval. }\end{array}$ \\
\hline 4 & Client POC & $\begin{array}{l}\text { Provides the MAID plan to all relevant } \\
\text { stakeholders for review. }\end{array}$ \\
\hline
\end{tabular}




\section{Artifact Evaluation}

1. Collaborative
planning $\longrightarrow \begin{aligned} & \text { 2. Artifact } \\ & \text { evaluation }\end{aligned} \longrightarrow \begin{aligned} & \text { 3. On-site } \\ & \text { evaluation }\end{aligned} \rightarrow \begin{aligned} & \text { 4. Report } \\ & \text { results }\end{aligned}$

Introduction

During Phase 2: Artifact Evaluation, the MAID team analyzes the client organization's M \& A artifacts that were inventoried during Phase 1: Collaborative Planning. The analysis is based on a predefined set of MAID criteria that were also identified during Phase 1 as part of the scope definition.

The outcome of this phase includes:

- a rating for each MAID criterion that is part of the evaluation,, with rationale for the rating

- a set of interview questions that will be used during Phase 3: On-site Evaluation

Before you begin

Stages
Before beginning this phase, the organization sponsor approves the MAID plan that was developed during Phase 1: Collaborative Planning.

The stages included in this phase are:

2.1 Prepare for Artifact Evaluation

2.2 Conduct $\mathrm{M} \& \mathrm{~A}$ Artifact Evaluation

2.3 Perform Quality Audit of Results

2.4 Prepare for On-Site Evaluation 


\subsection{Prepare for Artifact Evaluation}

\author{
Activity \\ description
}

Who

participates?

Information

needed

Procedure

Products

Additional

guidance
During this activity, the MAID team prepares to conduct the artifact evaluation. This involves obtaining the $M \& A$ artifacts from the client $P O C$, organizing the artifacts, and assigning team members to evaluate specific $M \& A$ artifacts.

- Team lead

- Team members

- Client POC

- $\quad$ List of MAID team members with contact information and availability information [1.2]

- List of client SMEs [1.2]

- $\quad M \& A$ artifact inventory [1.3.2]

- Approved MAID plan [1.3.5]

The table below describes the key tasks of this activity.

\begin{tabular}{|c|c|c|}
\hline Step & Who? & What happens? \\
\hline 1 & Client POC & $\begin{array}{l}\text { Provides a copy of each file listed in the } \\
\text { inventory to the MAID team lead. }\end{array}$ \\
\hline 2 & Team lead & Organizes the files into a repository. \\
\hline 3 & Team lead & $\begin{array}{l}\text { Assigns each file to a MAID team member } \\
\text { for evaluation. }\end{array}$ \\
\hline
\end{tabular}

$M \& A$ artifacts received from the client organization

Mechanisms must be put into place to control versioning of the artifacts. A master copy of each artifact should be stored away from the copies that will be used during the evaluation as Team Members will likely annotate the documents during their review. ${ }^{4}$

$4 \quad$ The notes made within the artifacts by the MAID team members during the evaluation activity are off record. These might include, for example, work-in-progress notes that assist the reviewers with their work but are not relevant to the evaluation outcome. 


\subsection{Conduct M \& A Artifact Evaluation}

\author{
Activity \\ description
}

Who

participates?

Information

needed

Procedure
During this activity, the MAID team members conduct analyses of $M \& A$ artifacts that are included in the MAID scope.

This activity describes the approach for evaluating a single $M$ \& $A$ artifact. The activity would be repeated for each $M \& A$ artifact that is included as part of the inventory.

- Team lead

- Team members

- $\quad$ Client POC

- $\quad$ Client SMEs

- $\quad M \&$ A artifact inventory [1.3.2]

- $\quad M \& A$ artifact received from the client organization [2.1]

- MAID criteria form

The table below describes the key tasks of this activity.

\begin{tabular}{|l|l|l|}
\hline Step & Who? & What happens? \\
\hline 1 & $\begin{array}{l}\text { Team } \\
\text { member }\end{array}$ & $\begin{array}{l}\text { Scans the artifact and tabs, highlights, or } \\
\text { annotates areas that are related to M \& A. }\end{array}$ \\
\hline 2 & $\begin{array}{l}\text { Team } \\
\text { member }\end{array}$ & $\begin{array}{l}\text { Reviews relevant M \& A areas in light of MAID } \\
\text { criteria that are relevant to the particular artifact. }\end{array}$ \\
\hline 3. & $\begin{array}{l}\text { Team } \\
\text { member }\end{array}$ & $\begin{array}{l}\text { Rates relevant MAID criteria. For each rating, a } \\
\text { reference to the artifact section is documented as } \\
\text { well as the rationale for the rating. }\end{array}$ \\
\hline 3 & $\begin{array}{l}\text { Team } \\
\text { lead }\end{array}$ & $\begin{array}{l}\text { Assesses progress of evaluation and facilitates } \\
\text { communication among team members and } \\
\text { between the team and the client. }\end{array}$ \\
\hline
\end{tabular}

Table continues on next page

5 In some cases, M \& A information is only a part or section of an artifact. Experience has shown that an initial scan of the document to locate these areas is better than a detailed page-by-page review. 


\section{Procedure,}

cont.

\begin{tabular}{|l|l|l|}
\hline Step & Who? & What happens? \\
\hline 4 & $\begin{array}{l}\text { Team lead, } \\
\text { Team members, } \\
\text { Client POC, } \\
\text { Client SME(s) }\end{array}$ & $\begin{array}{l}\text { Team lead sets up meeting with client } \\
\text { POC and client SMEs on an as-needed } \\
\text { basis to address need for clarification or } \\
\text { need for access to other information. }\end{array}$ \\
\hline 5 & Team lead & $\begin{array}{l}\text { Compiles and organizes the team } \\
\text { member results. Ratings and } \\
\text { accompanying information are } \\
\text { consolidated into one file to provide a } \\
\text { single view of the results. }\end{array}$ \\
\hline
\end{tabular}

The MAID criteria form
A spreadsheet can be used to capture the results of the evaluation. A separate worksheet can be used to record information for each MAID category (i.e., for M \& A Planning, Data Collection \& Storage, Data Analysis, M \& A Reporting, and M \& A - General).

The table below describes the information that should be captured when rating the satisfaction of each criterion.

\begin{tabular}{ll}
\hline $\begin{array}{l}\text { Item } \\
\text { Criterion }\end{array}$ & Description \\
number & $\begin{array}{l}\text { The number assigned to the criterion in the } \\
\text { document, Measurement and Analysis } \\
\text { Infrastructure Diagnostic (MAID) Evaluation } \\
\text { Criteria, Version } 1.0 \text { [SEMA 2009]. }\end{array}$ \\
\hline Criterion & The evaluation criterion description. \\
Rating & $\begin{array}{l}\text { The evaluator's rating of how well the criterion is } \\
\text { satisfied. }\end{array}$ \\
\hline Evidence for & $\begin{array}{l}\text { A pointer to the location within the artifact that is } \\
\text { rating }\end{array}$ \\
\hline being examined that supports the criterion rating. \\
Rationale & $\begin{array}{l}\text { The reasoning used by the evaluator to assign the } \\
\text { rating. This field is optional. It is used in cases } \\
\text { where the reason is not obvious and additional } \\
\text { explanation is necessary. }\end{array}$
\end{tabular}

Table continues on next page 


\section{The MAID criteria} form, cont.

\begin{tabular}{ll}
\hline Item & Description \\
\hline $\begin{array}{l}\text { Interview } \\
\text { question(s) }\end{array}$ & $\begin{array}{l}\text { This field is reserved for documenting interview } \\
\text { questions that will be used during Phase 3: On-site } \\
\text { Evaluation. The interview questions are typically } \\
\text { intended to clarify criterion issues that are not } \\
\text { elaborated clearly by the artifact being examined. }\end{array}$ \\
& $\begin{array}{l}\text { The notes field is intended to capture any other } \\
\text { information that the evaluator wants to record } \\
\text { about the criterion being investigated. }\end{array}$ \\
\hline
\end{tabular}

A rating is used to capture the evaluation of a criterion. Each criterion is rated using one and only one of the ratings listed below.

\begin{tabular}{ll}
\hline Rating & Description \\
\hline Very adequate & $\begin{array}{l}\text { Exceeds the standard for this criterion or is viewed } \\
\text { as a superior implementation. }\end{array}$ \\
\hline Adequate & Satisfies the criterion sufficiently. \\
\hline $\begin{array}{l}\text { Slightly } \\
\text { inadequate }\end{array}$ & $\begin{array}{l}\text { Criterion is almost satisfied. By making a slight } \\
\text { change to the condition or practice addressed by } \\
\text { the criterion, a rating of adequate could be } \\
\text { achieved. }\end{array}$ \\
\hline $\begin{array}{l}\text { Very } \\
\text { inadequate }\end{array}$ & $\begin{array}{l}\text { The condition or practice is addressed by the } \\
\text { organization but in an inadequate way. }\end{array}$ \\
\hline $\begin{array}{l}\text { Completely } \\
\text { missing }\end{array}$ & $\begin{array}{l}\text { The condition or practice does not exist based on } \\
\text { examination of the M \& A artifact. }\end{array}$ \\
\hline Doesn't apply & $\begin{array}{l}\text { The particular criterion does not apply to the } \\
\text { organizational context. }\end{array}$ \\
\hline
\end{tabular}

MAID criteria form - Phase 2 results that includes

- MAID criteria ratings

- evidence for ratings

- rationale for ratings

- potential interview questions 


\section{Additional guidance}

- It is helpful when documents are provided in a format that can be edited by the evaluator (for example, to allow the addition of comments, annotations, and bookmarks). However some M \& A artifacts may be provided in portable document format (PDF) or in a graphic format language (such as JPEG). In these cases, the MAID evaluator may want to invest in applications that provide the capability to annotate such artifacts. Using this approach, digital copies of comments or annotations can be preserved.

- A spreadsheet can be used to capture the results of the evaluation and automatically tally the criteria ratings.

- While reviewing and evaluating an artifact, other questions and issues not directly related to a specific criterion may emerge. These should be recorded in a separate document template.

- Lessons learned regarding the MAID method should also be recorded in a separate document template. These lessons should be compiled by the team lead and shared. They should also be considered as improvement opportunities for future MAID efforts.

- During Phase 2: Artifact Evaluation, the team leader should check in with other members to assess progress and determine if the evaluation is on track. Members should share their intermediate work with the team leader as the evaluation is being carried out. The team leader can review the work-in-progress and provide feedback (e.g., as to whether rationale is being documented sufficiently).

- In some cases, there will be questions about an M \& A artifact that require resolution in order to continue the evaluation in an efficient and effective way. For example, parochial terminology or undefined organizational acronyms might be used in an artifact.

Instances such as these should be noted and a meeting or some other form of communication should be scheduled with the client POC by the team lead.

SMEs may be requested to participate in a meeting or teleconference to clarify an issue so the evaluation can continue.

- Team members should meet during the evaluation to discuss their experience and any lessons learned that could help other members as they continue their evaluation. 


\subsection{Perform Quality Audit of Results}

\author{
Activity \\ description
}

Who

participates?

Information

Needed

Procedure

The table below describes the key tasks of this activity.

\begin{tabular}{|c|c|c|}
\hline Step & Who? & What happens? \\
\hline 1 & Team lead & $\begin{array}{l}\text { Reviews the consolidated results and } \\
\text { checks for the following: } \\
\text { - all criteria have been rated } \\
\text { - } \quad \text { evidence is provided for all ratings } \\
\text { when appropriate } \\
\text { - rationale for each rating is provided if } \\
\text { evaluator's reasoning is not self- } \\
\text { evident } \\
\text { - candidate interview questions (for } \\
\text { Phase 3: On-site Evaluation) are clear } \\
\text { and understandable }\end{array}$ \\
\hline 2 & $\begin{array}{l}\text { Team lead, } \\
\text { Team member }\end{array}$ & $\begin{array}{l}\text { Resolve any issues that the team lead } \\
\text { could not resolve during step } 1 .\end{array}$ \\
\hline
\end{tabular}

Products

During this activity, the team lead conducts a thorough review of the compiled results.

- Team lead

- Team members

MAID criteria form - Phase 2 results [2.2]

Quality-audited MAID criteria form - Phase 2 results

6 That is, all MAID criteria which are included within the scope. 


\subsection{Prepare for On-Site Evaluation}

Overview

Activities during

this stage
During this activity, preparations are made for conducting the on-site evaluation. Informational materials are prepared to support interview sessions and a detailed agenda is coordinated for the on-site evaluation.

This stage comprises the following activities:

2.4.1 Prepare On-site Evaluation Agenda

2.4.2 Prepare Materials

2.4.3 Administer MAID Questionnaire

2.4.4 Manage Logistics 


\subsubsection{Prepare On-Site Evaluation Agenda}

\author{
Activity \\ description
}

Who

participates?

Information

needed

Procedure
During this activity, the team lead works closely with the client POC to put together a detailed plan for the on-site evaluation.

- Team lead

- $\quad$ Client POC

- $\quad M \& A$ artifact inventory [1.3.2]

- Approved MAID plan [1.3.5]

- Quality-audited MAID criteria form - Phase 2 results [2.3]

The table below describes the key tasks of this activity.

\begin{tabular}{|c|c|c|}
\hline Step & Who? & What happens? \\
\hline 1 & Team lead & $\begin{array}{l}\text { Using the } M \& A \text { artifact inventory and the } \\
\text { Quality-audited Phase } 2 \text { artifact evaluation } \\
\text { results, creates a separate document and } \\
\text { organizes the list of interview questions } \\
\text { according to the client SME responsible for } \\
\text { the artifact. }\end{array}$ \\
\hline 2 & Team lead & $\begin{array}{l}\text { Estimates the amount of time required to } \\
\text { interview each client SME based on the } \\
\text { results of step } 1 \text { and the list in the draft } \\
\text { agenda. }\end{array}$ \\
\hline 3 & Team lead & $\begin{array}{l}\text { Reviews the Approved MAID plan, identifies } \\
\text { other evaluation activities that are included in } \\
\text { the plan, estimates the duration, and adds to } \\
\text { the draft agenda. }\end{array}$ \\
\hline 4 & Team lead & $\begin{array}{l}\text { Identifies any other needed activities (e.g., } \\
\text { MAID orientation presentation, MAID team } \\
\text { prep and analysis sessions, outbrief } \\
\text { presentation preparation, outbrief reporting), } \\
\text { estimates duration of these activities and adds } \\
\text { to the draft agenda. }\end{array}$ \\
\hline
\end{tabular}


Procedure, cont. The table below describes the key tasks of this activity.

\begin{tabular}{|c|c|c|}
\hline Step & Who? & What happens? \\
\hline 5 & Team lead & $\begin{array}{l}\text { Organizes the information from steps } 1-4 \\
\text { into a draft on-site agenda that includes the } \\
\text { following: } \\
\text { - } \text { activity } \\
\text { - } \text { who participates in activity } \\
\text { - } \text { start and stop time } \\
\text { - } \text { activity duration } \\
\text { - } \text { brief activity description }\end{array}$ \\
\hline 6 & $\begin{array}{l}\text { Team lead, } \\
\text { Client POC }\end{array}$ & $\begin{array}{l}\text { Team lead reviews the draft agenda with } \\
\text { the client POC and makes any necessary } \\
\text { adjustments. }\end{array}$ \\
\hline 7 & $\begin{array}{l}\text { Client POC, } \\
\text { Client SMEs, } \\
\text { Stakeholders, } \\
\text { Sponsor }\end{array}$ & $\begin{array}{l}\text { Client POC reviews the draft agenda with } \\
\text { all individuals who participate in any activity } \\
\text { identified on the agenda. Change requests } \\
\text { are recorded by the client POC. }\end{array}$ \\
\hline 8 & $\begin{array}{l}\text { Client POC, } \\
\text { Team lead }\end{array}$ & $\begin{array}{l}\text { Client } \mathrm{POC} \text { communicates change } \\
\text { requests to the team lead. }\end{array}$ \\
\hline 9 & Team lead & $\begin{array}{l}\text { Revises the agenda and reviews the } \\
\text { changes with the client POC who then } \\
\text { approves the agenda. }\end{array}$ \\
\hline
\end{tabular}

Products

\section{Additional guidance}

Approved agenda for on-site evaluation

See Appendix B on page 69 for an example of an Approved agenda for on-site evaluation. 


\title{
2.4.2 Prepare Materials
}

\begin{abstract}
Activity description

During this activity, materials that support the on-site evaluation are prepared.
\end{abstract}

Who

participates?

Information needed

Procedure
- Team lead

- Team members

- $\quad M \& A$ artifact inventory [1.3.2]

- Approved MAID plan [1.3.5]

- Approved agenda for on-site evaluation [2.4.1]

- Quality-audited MAID criteria form - Phase 2 results [2.3]

The table below describes the key tasks of this activity.

\begin{tabular}{|l|l|l|}
\hline Step & Who? & What happens? \\
\hline 1 & Team lead & $\begin{array}{l}\text { Organizes a list of questions for each client } \\
\text { SME that will be interviewed. Part of this step } \\
\text { was performed during Activity 2.4.1 to } \\
\text { estimate the duration of an interview. Here, } \\
\text { the questions are refined and sequenced into } \\
\text { an interview script. }\end{array}$ \\
\hline 2 & Client POC & $\begin{array}{l}\text { Develops a list of individual stakeholders that } \\
\text { will be surveyed about M \& A practices in their } \\
\text { organizations. If survey is Internet-based, then } \\
\text { email addresses for each individual are } \\
\text { provided. }\end{array}$ \\
\hline 3 & Team lead & $\begin{array}{l}\text { Develops a self-administered questionnaire to } \\
\text { solicit additional input from all stakeholders in } \\
\text { the M \& A system. }\end{array}$ \\
\hline 4 & Team lead & $\begin{array}{l}\text { Develops an orientation briefing that will be } \\
\text { used at the start of the Phase 3: On-Site } \\
\text { Evaluation. }\end{array}$ \\
\hline
\end{tabular}


Products

Additional guidance
- Interview questions organized by interviewee

- Contact list for questionnaire target audience

- Self-administered questionnaire

- Orientation presentation from Phase 3: On-site Evaluation

- Interview questions organized by interviewee

Information gleaned from the survey results may provide motivation for additional probing questions about the organization's M \& A practices. For example, respondents might suggest that actual practices do not always adhere to the documented $M \& A$ practices. Based on such information, the MAID evaluation team may decide to validate such assertions during the on-site evaluation.

Many interview questions from the product Quality-audited Phase 2 artifact evaluation results will be used to develop the interview questions. However, additional questions are added that ask about compliance to the documented $M \& A$ plans and procedures.

- Contact list for questionnaire target audience

In many cases, it is impractical to interview every stakeholder in the organization's M \& A program. A survey can be used to obtain opinions about the $M \& A$ program and provide an additional perspective on implementation issues.

The contact list will include email addresses when the questionnaire is to be administered over the Internet. There are many easy-to-use web-based products that can be used to implement the survey.

- $\quad$ Self-administered questionnaire

The questionnaire will solicit feedback on the implementation of the $M \& A$ program. It can be distributed to everyone who is associated with the $M \& A$ program.

The MAID questionnaire can be distributed as a paper form or as a web-based instrument. A web-based instrument has many advantages, including ease of distribution and automated support for tracking and data collection.

For additional guidance on developing a survey, see the SEI handbook Designing Effective Surveys [Kasunic 2005].

Questionnaire item examples are provided in Appendix C. 
Additional guidance, cont.
- Orientation presentation from Phase 3: On-site Evaluation

The orientation provides a way to help ensure that all stakeholders have a shared understanding of what MAID is and is not. At a minimum, the presentation covers

- the objectives and benefits of the MAID method

- a summary of the MAID method by phase

- a review of the agenda for the duration of the on-site evaluation

- a summary of what happens during the interview sessions

$\circ \quad Q \& A$

Generally speaking, the presentation should be tailored to the information needs of the audience. It should also address any issues or concerns that the audience might have.

The MAID team leader should review the presentation with the client POC to test whether the presentation is on target for the audience. 


\subsubsection{Administer MAID Questionnaire}

\author{
Activity \\ description
}

Who

participates?

Information

needed

Procedure
The MAID questionnaire is an instrument that provides an additional way of collecting information about the organization's M \& A practices. The questionnaire is a valuable input as it can be used to obtain feedback from all staff members who are impacted by the organization's M \& A program.

- Team lead

- Questionnaire respondents

- Contact list for questionnaire target audience [2.4.2]

- Self-administered questionnaire [2.4.2]

- Interview questions organized by interviewee [2.4.2]

The table below describes the key tasks of this activity.

\begin{tabular}{|c|c|c|}
\hline Step & Who? & What happens? \\
\hline 1 & MAID Lead & $\begin{array}{l}\text { Using the Contact list for questionnaire target } \\
\text { audience as a source, an invitation to } \\
\text { participate in the MAID survey is sent to } \\
\text { questionnaire respondents. }\end{array}$ \\
\hline 2 & $\begin{array}{l}\text { Questionnaire } \\
\text { respondents }\end{array}$ & Complete the questionnaire. \\
\hline 3 & MAID Lead & Analyzes survey results. \\
\hline 4 & MAID Lead & $\begin{array}{l}\text { Based on results, determines if probing } \\
\text { questions should be added to the Interview } \\
\text { questions organized by interviewees; adds } \\
\text { questions if appropriate. }\end{array}$ \\
\hline 5 & MAID Lead & $\begin{array}{l}\text { Formats the questionnaire results for } \\
\text { reporting purposes (i.e., creates graphical } \\
\text { rendering). }\end{array}$ \\
\hline
\end{tabular}


Additional

guidance

Products
- The questionnaire results are rolled into the overall MAID results and reported to the sponsor during Phase 4: Report Results. However, the results can be prepared at this time by developing illustrative graphs and tables that can be inserted into the final report.

- Questionnaire results

- Revised interview questions organized by interviewee (if applicable)

- Questionnaire results organized for reporting purposes 


\subsubsection{Manage Logistics}

\section{Activity description}

Who participates?

Information needed

Procedure

Products
During this activity, the logistical details of the on-site evaluation are negotiated and documented. Checklists and action item tracking mechanisms are effective ways to manage and track these tasks.

- Team lead

- Client POC

- Approved MAID plan [1.3.5]

- $\quad$ Approved agenda for on-site evaluation [2.4.1]

The table below describes the key tasks of this activity.

\begin{tabular}{|l|l|l|}
\hline Step & Who? & What happens? \\
\hline 1 & Team lead & $\begin{array}{l}\text { Develops an action item list to plan and } \\
\text { document logistical tasking. }\end{array}$ \\
\hline 2 & $\begin{array}{l}\text { Team lead, } \\
\text { Client POC }\end{array}$ & $\begin{array}{l}\text { Plan the details of the on-site evaluation and } \\
\text { add tasks to the action item list. }\end{array}$ \\
\hline 3 & Team lead & Updates the action item list as needed. \\
\hline
\end{tabular}

Action item list (to support Phase 3: On-site Evaluation) 
Additional guidance
The action item list template should include columns for the following information:

- task description

- task responsibility

- task due date

- task completion date

The person managing the action item list should ensure the following:

- the list is shared with all individuals who are responsible for a task that appears in the list

- version control is maintained

- a new version is emailed to affected individuals whenever there is an addition to the list, or the list should be maintained in a shared repository

Examples of actions needed to support Phase 3: On-site Evaluation:

- communicating with individuals who will be interviewed during this phase (e.g., a "what-to-expect" email)

- transportation to and from the site

- identifying hotels for individuals traveling to the site

- ordering meals or identifying nearby restaurants

- arranging for a conference room or other appropriate space to conduct the on-site orientation meeting

- arranging for a conference room or other appropriate space to conduct interviews

- arranging private work space for the MAID team to conduct off-line work

- meeting security requirements at the site (e.g., getting visitor badges)

- obtaining access to databases that are part of the MAID scope

- arranging access to equipment such as printers and copiers and other supplies 
48 | CMU/SEI-2010-TR-035 


\section{On-Site Evaluation}

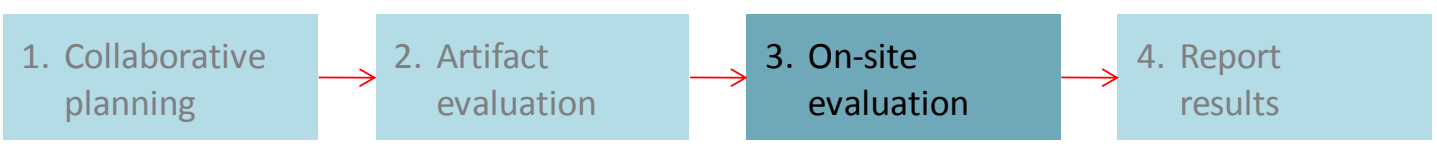

Introduction

During Phase 3: On-Site Evaluation, the MAID team conducts a number of interviews and examinations at the organization's site. These include

- interviews with client SMEs ${ }^{7}$

- interviews with stakeholders

- examination of M \& A data repositories

- examination of any $M \& A$ artifact that could not be evaluated off-site

Before you begin

Stages
All required actions recorded in the action item list need to be sufficiently addressed (see Activity 2.4.3) before beginning this phase.

The stages included in this phase are

3.1 Conduct Orientation Meeting

3.2 Conduct Examinations of M \& A Data Repositories

3.3 Conduct Interviews

7 In some cases, the sponsor may also be an SME. 


\subsection{Conduct Orientation Meeting}

\section{Activity description}

Who participates?

Information needed

Procedure
An orientation meeting is the first activity of the on-site evaluation. The purpose of the meeting is to

- provide an overview of MAID, including objectives and benefits

- describe what will happen during the on-site evaluation

- answer questions from the audience

- Team lead

- Team members

- Client POC

- Sponsor

- Client SMEs

- Stakeholders

- $\quad$ Approved agenda for on-site evaluation [2.4.1]

- Orientation presentation from Phase 3: On-site Evaluation [2.4.2]

The table below describes the key tasks of this activity.

\begin{tabular}{|c|c|c|}
\hline Step & Who? & What happens? \\
\hline 1 & Client POC & $\begin{array}{l}\text { Before the meeting, } \\
\text { - } \quad \text { prepares conference room for the meeting } \\
\text { - ensures that a projection system is in } \\
\text { operating order }\end{array}$ \\
\hline 2 & Sponsor & $\begin{array}{l}\text { Kicks off the meeting by emphasizing support } \\
\text { for this effort and the benefits that will be } \\
\text { derived from the MAID evaluation (sponsor } \\
\text { perspective). }\end{array}$ \\
\hline 3 & Client POC & Introduces the MAID team. \\
\hline
\end{tabular}


Procedure, cont.

\begin{tabular}{|c|c|c|}
\hline Step & Who? & What happens? \\
\hline 4 & Team lead & $\begin{array}{l}\text { - Presents brief MAID overview to provide } \\
\text { context } \\
\text { - Presents the agenda for the on-site } \\
\text { evaluation } \\
\text { - Describes what has already happened } \\
\text { (i.e., during Phase 1: Collaborative } \\
\text { Planning and Phase 2: Artifact Evaluation) } \\
\text { - Describes the MAID questionnaire (if } \\
\text { applicable) } \\
\text { Describes what will happen during the } \\
\text { interviews } \\
\text { Describes what will happen after the on- } \\
\text { site evaluation } \\
\text { Conducts question and answer session }\end{array}$ \\
\hline $1-4$ & $\begin{array}{l}\text { Team } \\
\text { member }\end{array}$ & $\begin{array}{l}\text { Records issues, action items, or any } \\
\text { observations to support post-MAID lessons } \\
\text { learned. }\end{array}$ \\
\hline
\end{tabular}

\section{Products}

Orientation meeting record 


\subsection{Conduct Examinations of M \& A Data Repositories}

\author{
Activity \\ description
}

Who

participates?

Information

needed

Procedure

Products

Additional

guidance
During this activity, MAID team members examine M \& A data repositories that are included in the MAID scope.

A number of MAID evaluation criteria address data quality and storage mechanisms. These criteria are rated as an outcome of the evaluation. Also, other MAID criteria address procedural aspects of how data is stored and managed. During this examination, the MAID team members validate that the implementation follows the documented procedures.

- $\quad$ Team member(s) ${ }^{8}$

- Client SME

- Quality-audited Phase 2 artifact evaluation results [2.3]

- Client M \& A repository

The table below describes the key tasks of this activity.

\begin{tabular}{|l|l|l|}
\hline Step & Who? & What happens? \\
\hline 1 & $\begin{array}{l}\text { Client POC or } \\
\text { Client SME }\end{array}$ & $\begin{array}{l}\text { Provides access for team members to the } \\
\text { client data repository to be examined. }\end{array}$ \\
\hline 2 & $\begin{array}{l}\text { Team } \\
\text { member(s) }\end{array}$ & $\begin{array}{l}\text { Examines the M \& A data repository and } \\
\text { rates the applicable MAID criteria. }\end{array}$ \\
\hline
\end{tabular}

Intermediate Phase 2-3 artifact evaluation results

- Criteria listed in the MAID criteria category "Data Collection \& Storage" will be particularly relevant to this examination.

- This examination provides an opportunity to investigate whether implementation follows $M$ \& A documented plans and procedures.

8 The team lead could also fill the role of team member. 


\subsection{Conduct Interviews}

\begin{abstract}
Activity description

During this activity, client SMEs are interviewed about the $M$ \& $A$ practices of their organization.
\end{abstract}

Who participates?

Information needed

Procedure

Products

- Team member(s)

- Client SMEs

- Interview questions organized by interviewee [2.4.2]

- Intermediate Phase 2-3 artifact evaluation results [3.2]

The table below describes the key tasks of this activity.

\begin{tabular}{|l|l|l|}
\hline Step & Who? & What happens? \\
\hline 1 & $\begin{array}{l}\text { Team } \\
\text { members }\end{array}$ & $\begin{array}{l}\text { Before the interview, the team members } \\
\text { review the questions to prepare for the } \\
\text { interview. }\end{array}$ \\
\hline 2 & $\begin{array}{l}\text { Team } \\
\text { members, } \\
\text { Client SMEs }\end{array}$ & $\begin{array}{l}\text { During the interview, one team member acts } \\
\text { as primary interviewer while other team } \\
\text { member(s) record the interview responses. }\end{array}$ \\
\hline 3 & $\begin{array}{l}\text { Team } \\
\text { members }\end{array}$ & $\begin{array}{l}\text { After the interview, the team members review } \\
\text { the interview transcript for accuracy and } \\
\text { completeness and revise transcript if } \\
\text { necessary. }\end{array}$ \\
\hline
\end{tabular}

Interview transcripts

$9 \quad$ The team lead could also fill the role of team member. 
Additional guidance
- At least two team members are needed for each interview. One member moderates the interview and the other member records interviewee responses.

- $\quad$ The product Intermediate Phase 2-3 artifact evaluation results is available as a reference during the interviews in the event that team members want to refer to information in it.

- Further guidance for conducting interviews is provided in Appendix D. 


\section{$4 \quad$ Report Results}

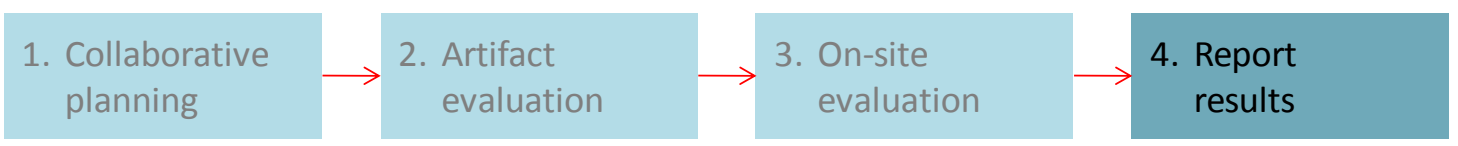

Introduction During Phase 4: Report Results, the MAID team compiles the results from Phases 2 and 3 to generate a report that is delivered to the client. The report can be mediated in a number of ways.

Stages The stages included in this phase are:

4.1 Analyze On-site Evaluation Results

4.2 Derive Key Findings

4.3 Deliver Key Findings

4.4 Plan Next Steps 


\subsection{Analyze On-Site Evaluation Results}

\section{Activity description}

Who participates?

Information needed

Procedure

Products
During this activity, MAID team members compile and analyze the results from the on-site examinations, including

- interview transcripts

- $\quad M \& A$ database examinations

- $\quad$ any other M \& A artifacts that were evaluated during Phase 2: Artifact Evaluation ${ }^{10}$

- Team lead

- Team members

- Intermediate Phase 2-3 artifact evaluation results [3.2]

- Interview transcripts [3.3]

The table below describes the key tasks of this activity.

\begin{tabular}{|l|l|l|}
\hline Step & Who? & What happens? \\
\hline 1 & $\begin{array}{l}\text { Team lead, } \\
\text { Team member(s) }\end{array}$ & $\begin{array}{l}\text { Review interview transcripts and update } \\
\text { the Intermediate Phase 2-3 artifact } \\
\text { evaluation results. }\end{array}$ \\
\hline 2 & $\begin{array}{l}\text { Team lead, } \\
\text { Team member(s) }\end{array}$ & $\begin{array}{l}\text { If there are any other artifacts that have } \\
\text { been examined, then the Intermediate } \\
\text { Phase 2-3 artifact evaluation results are } \\
\text { updated. }\end{array}$ \\
\hline
\end{tabular}

Final MAID criteria evaluation results

10 This may include planning and process/procedure documentation that was not included as part of the Phase 2 evaluations. 


\subsection{Derive Key Findings}

\author{
Activity \\ description
}

Who

participates?

Information

needed

Procedure
During this activity, MAID team members prepare the results for reporting to the client organization. The evaluation results are reviewed in light of the MAID objectives and the MAID plan. The results are translated into key findings that summarize strengths and weaknesses. The Final MAID criteria evaluation results can be included as an appendix to the report.

- Team lead

- Team members

- $\quad$ List of client SMEs [1.2]

- Approved MAID plan [1.3.5]

- Questionnaire results organized for reporting purposes [2.4.3]

- Final MAID criteria evaluation results [4.1]

The table below describes the key tasks of this activity.

\begin{tabular}{|l|l|l|}
\hline Step & Who? & What happens? \\
\hline 1 & $\begin{array}{l}\text { Team lead, } \\
\text { Team member(s) }\end{array}$ & $\begin{array}{l}\text { Review the list of outputs with descriptions } \\
\text { that will be developed based on the } \\
\text { results of the MAID scope that was } \\
\text { included in the Approved MAID plan. }\end{array}$ \\
\hline 2 & $\begin{array}{l}\text { Team lead, } \\
\text { Team member(s) }\end{array}$ & $\begin{array}{l}\text { Develop an annotated outline of the MAID } \\
\text { report. }\end{array}$ \\
\hline 3 & $\begin{array}{l}\text { Team lead, } \\
\text { Team member(s) }\end{array}$ & $\begin{array}{l}\text { Validate that the outline developed in step } \\
\text { 2 addresses the List of MAID objectives } \\
\text { that should be included in the plan. }\end{array}$ \\
\hline
\end{tabular}


Procedure,

Continued

\begin{tabular}{|l|l|l|}
\hline Step & Who? & What happens? \\
\hline 4 & $\begin{array}{l}\text { Team lead, Team } \\
\text { members }\end{array}$ & $\begin{array}{l}\text { Using the Final MAID criteria } \\
\text { evaluation results as a reference } \\
\text { prepare a list of findings that are } \\
\text { representative of the results in each } \\
\text { MAID criteria category that was } \\
\text { included in the scope. }\end{array}$ \\
\hline 5 & Team lead & $\begin{array}{l}\text { Publishes the Final MAID criteria } \\
\text { evaluation findings. }\end{array}$ \\
\hline
\end{tabular}

Products

Final MAID criteria evaluation findings 


\subsection{Deliver Key Findings}

\section{Activity description}

Who

participates?

Information needed
The key findings contain a summary of the strengths and weaknesses of the organization's M \& A program. These findings can be accompanied by the detailed evaluation results that were used to generate the findings.

The key findings should be delivered in a way that supports decision making and future $M \& A$ planning.

How the key findings are communicated is decided during Phase 1: Collaborative Planning. The findings can be delivered in the following formats:

- an executive summary of key findings

- a detailed slide presentation

- a detailed textual report

- a combination of the above

- Team lead

- Team members (optional)

- Sponsor

- Client POC

- Client SMEs

- Questionnaire respondents

- Stakeholders

Final MAID criteria evaluation findings [4.2] 
The table below describes the key tasks of this activity.

\begin{tabular}{|l|l|l|}
\hline Step & Who? & What happens? \\
\hline 1 & $\begin{array}{l}\text { Team lead, Client } \\
\text { POC }\end{array}$ & $\begin{array}{l}\text { Team lead and client POC negotiate a } \\
\text { list of potential dates and times for } \\
\text { delivery of the report. }\end{array}$ \\
\hline 2 & $\begin{array}{l}\text { Client POC, } \\
\text { Client SMEs, } \\
\text { Questionnaire } \\
\text { respondents, } \\
\text { If an oral presentation of the results } \\
\text { (supported by slides) is to be }\end{array}$ \\
\hline 3 & $\begin{array}{l}\text { Stakeholders } \\
\text { delivered, the client POC coordinates } \\
\text { a date/time that optimizes attendance } \\
\text { by organization members. }\end{array}$ \\
\hline
\end{tabular}

Products

Additional guidance
Delivered MAID results

When presenting results, it is important that information is not attributable to any single individual within the organization. The commitment of non-attribution during the interviewing process must be upheld. 


\subsection{Plan Next Steps}

\author{
Activity \\ description
}

Who

participates?

Information

needed

Procedure

Products

Additional guidance
Planning next steps is an optional activity but is recommended.

Follow-on activities may include

- delivery of a detailed report, if it was not originally included in the Approved MAID plan [1.3.5]

- generation of an action plan to address the MAID findings

- Sponsor

- Stakeholders

- Team lead

Delivered MAID results [4.3]

The table below describes the key tasks of this activity.

\begin{tabular}{|l|l|l|}
\hline Step & Who? & What happens? \\
\hline 1 & $\begin{array}{l}\text { Sponsor, Team } \\
\text { lead }\end{array}$ & $\begin{array}{l}\text { Negotiate the role that MAID team lead } \\
\text { will play during this activity. }\end{array}$ \\
\hline 2 & $\begin{array}{l}\text { Sponsor, } \\
\text { Stakeholders, } \\
\text { Team lead } \\
\text { (optional) }\end{array}$ & $\begin{array}{l}\text { Identify specific next steps to address the } \\
\text { findings reported in the Delivered MAID } \\
\text { results. }\end{array}$ \\
\hline
\end{tabular}

Action plan

- In addition to specifying the follow-on activities that are to be performed, the action plan typically includes the assignment of responsibility for performing each activity, a schedule, and estimated resources.

- One outcome of this activity might be the development of a detailed MAID final report with recommendations, if this is something that was not originally contracted for during Phase 1: Collaborative Planning. 
62 | CMU/SEI-2010-TR-035 


\section{Appendix A: MAID Summary}

\begin{tabular}{|c|c|c|c|}
\hline Sec. & Title & Information Needed & Products \\
\hline 1. & Collaborative Planning & & \\
\hline 1.1 & Establish Scope & & \\
\hline 1.1 .1 & Determine Maid Objectives & $\begin{array}{l}\text { - Description of the organization's business } \\
\text { goals or business needs }\end{array}$ & List of MAID objectives \\
\hline 1.1 .2 & Determine Constraints & $\begin{array}{l}\text { - } \quad \text { List of MAID objectives [1.1.1] } \\
\text { - } \quad \text { Estimates of personnel availability }\end{array}$ & $\begin{array}{l}\text { - List of constraints to be met (accompanied by } \\
\text { rationale for decisions made) } \\
\text { - } \quad \text { List of personnel availability } \\
\text { - } \quad \text { List of revised MAID objectives (based on the } \\
\text { results of this activity) }\end{array}$ \\
\hline 1.1 .3 & Determine MAID Scope & $\begin{array}{l}\text { - } \quad \text { List of revised MAID objectives [1.1.2] } \\
\text { - } \quad \text { List of constraints to be met [1.1.2] }\end{array}$ & $\begin{array}{l}\text { - MAID scope statement that includes: } \\
\text { - } \quad \text { identification of organizational entities that } \\
\text { - } \text { will be included in the MAID evaluation } \\
\text { - identification of MAID criteria categories } \\
\text { that will be used for each organizational } \\
\text { entity } \\
\text { - } \quad \text { rationale for decisions made }\end{array}$ \\
\hline
\end{tabular}




\begin{tabular}{|c|c|c|c|}
\hline Sec. & Title & Information Needed & Products \\
\hline 1.2 & $\begin{array}{l}\text { Establish Roles and } \\
\text { Expectations }\end{array}$ & & $\begin{array}{l}\text { - List of MAID team members with contact } \\
\text { information and availability information } \\
\text { - } \quad \text { List of client SMEs that includes the following } \\
\text { descriptors } \\
- \text { name } \\
-\quad \text { contact information (phone, email) } \\
-\quad \text { organization/project } \\
-\quad \text { organization/project title } \\
-\quad \text { M \& A role in organization } \\
-\quad \text { M \& A SME area designation - within } \\
\text { MAID scope } \\
-\quad \text { availability information }\end{array}$ \\
\hline 1.3 & Develop Plan and Schedule & & \\
\hline 1.3.1 & Determine MAID Outputs & $\begin{array}{l}\text { - } \quad \text { List of revised MAID objectives [1.1.2] } \\
\text { - } \quad \text { Input from Sponsor to client POC }\end{array}$ & $\begin{array}{l}\text { List of outputs with descriptions that will be } \\
\text { developed based on the results of the MAID }\end{array}$ \\
\hline 1.3 .2 & Determine MAID Inputs & - List of client SMEs [1.2] & $M \& A$ artifact inventory \\
\hline 1.3 .3 & Tailor Method & $\begin{array}{l}\text { - } \quad \text { List of revised MAID objectives [1.1.2] } \\
\text { - } \quad \text { List of constraints to be met accompanied } \\
\text { by rationale for decisions made [1.1.2] } \\
\text { - MAID scope statement [1.1.3] }\end{array}$ & Approved tailoring decisions \\
\hline
\end{tabular}




\begin{tabular}{|c|c|c|c|}
\hline Sec. & Title & Information Needed & Products \\
\hline 1.3 .4 & $\begin{array}{l}\text { Determine Cost and } \\
\text { Schedule }\end{array}$ & $\begin{array}{l}\text { - } \quad \text { List of revised MAID objectives [1.1.2] } \\
\text { - } \quad \text { MAID scope statement [1.1.3] } \\
\text { - } \quad \text { Approved tailoring decisions [1.3.3] }\end{array}$ & $\begin{array}{l}\text { Approved cost and schedule estimates for MAID } \\
\text { effort }\end{array}$ \\
\hline 1.3 .5 & $\begin{array}{l}\text { Obtain Commitment to the } \\
\text { Plan }\end{array}$ & $\begin{array}{l}\text { - List of MAID revised Objectives [1.1.2] } \\
\text { - } \quad \text { List of personnel availability [1.1.2] } \\
\text { - The following parts of the MAID scope } \\
\text { statement [1.1.3]: } \\
\text { - Identification of organizational entities } \\
\text { that will be included in the MAID } \\
\text { evaluation } \\
\text { - Identification of MAID criteria categories } \\
\text { that will be used for each organizational } \\
\text { entity } \\
\text { - Approved cost and schedule estimates for } \\
\text { MAID effort [1.3.4] }\end{array}$ & Approved MAID plan \\
\hline 2 & Artifact Evaluation & & \\
\hline 2.1 & Prepare for Artifact Evaluation & 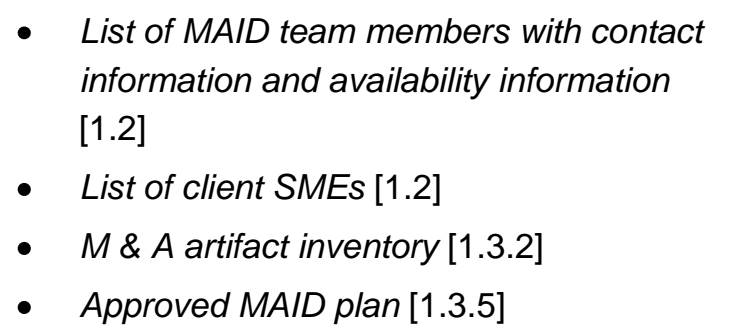 & $\begin{array}{l}M \& A \text { artifacts received from the client } \\
\text { organization }\end{array}$ \\
\hline
\end{tabular}




\begin{tabular}{|c|c|c|c|}
\hline Sec. & Title & Information Needed & Products \\
\hline 2.2 & $\begin{array}{l}\text { Conduct M \& A Artifact } \\
\text { Evaluation }\end{array}$ & $\begin{array}{l}\text { - } \quad M \& A \text { artifact inventory [1.3.2] } \\
\text { - } \quad M \& A \text { artifacts received from the client } \\
\text { organization [2.1] } \\
\text { - } \quad M A I D \text { criteria form }\end{array}$ & $\begin{array}{l}\text { MAID criteria form - Phase } 2 \text { results that includes } \\
\text { - } \text { MAID criteria ratings } \\
\text { - } \text { evidence for ratings } \\
\text { - } \text { rationale for ratings } \\
\text { - potential interview questions }\end{array}$ \\
\hline 2.3 & Perform Quality Audit of Results & MAID criteria form - Phase 2 results [2.2] & $\begin{array}{l}\text { Quality-audited MAID criteria form - Phase } 2 \\
\text { results }\end{array}$ \\
\hline 2.4 & Prepare for On-Site Evaluation & & \\
\hline 2.4.1 & $\begin{array}{l}\text { Prepare On-Site Evaluation } \\
\text { Agenda }\end{array}$ & $\begin{array}{l}\text { - } \quad M \& \text { A artifact inventory [1.3.2] } \\
\text { - } \quad \text { Approved MAID plan [1.3.5] } \\
\text { - } \quad \text { Quality-audited MAID criteria form- } \\
\quad \text { Phase } 2 \text { results [2.3] }\end{array}$ & Approved agenda for on-site evaluation \\
\hline 2.4 .2 & Prepare Materials & $\begin{array}{ll}\text { - } & \text { M \& A artifact inventory [1.3.2] } \\
\text { - } & \text { Approved MAID plan [1.3.5] } \\
\text { - } & \text { Approved agenda for on-site evaluation } \\
& {[2.4 .1]} \\
\text { - } & \text { Quality-audited MAID criteria form - } \\
& \text { Phase } 2 \text { results [2.3] }\end{array}$ & $\begin{array}{l}\text { - Interview questions organized by interviewee } \\
\text { - } \quad \text { Contact list of questionnaire target audience } \\
\text { - } \quad \text { Self-administered questionnaire } \\
\text { - } \quad \text { Orientation presentation from Phase 3: On-site } \\
\quad \text { Evaluation }\end{array}$ \\
\hline
\end{tabular}




\begin{tabular}{|c|c|c|c|}
\hline Sec. & Title & Information Needed & Products \\
\hline 2.4.3 & $\begin{array}{l}\text { Administer MAID } \\
\text { Questionnaire }\end{array}$ & $\begin{array}{l}\text { - } \begin{array}{l}\text { Contact list for questionnaire target } \\
\text { - }\end{array} \text { Self-adience [2.4.2] } \\
\text { - Interview questions organized by } \\
\text { interviewee [2.4.2] }\end{array}$ & $\begin{array}{l}\text { - } \quad \text { Questionnaire results } \\
\text { - Revised interview questions organized by } \\
\text { interviewee (if applicable) } \\
\text { - } \quad \text { Questionnaire results organized for reporting } \\
\text { purposes }\end{array}$ \\
\hline 2.4.4 & Manage Logistics & $\begin{array}{l}\text { - } \quad \text { Approved MAID plan [1.3.5] } \\
\text { - } \quad \text { Approved agenda for on-site evaluation } \\
\text { [2.4.1] }\end{array}$ & $\begin{array}{l}\text { Action item list (to support Phase 3: On-site } \\
\text { Evaluation) }\end{array}$ \\
\hline 3 & On-Site Evaluation & & \\
\hline 3.1 & Conduct Orientation Meeting & $\begin{array}{l}\text { - Approved agenda for on-site evaluation } \\
\text { [2.4.1] } \\
\text { - Orientation presentation from Phase 3: } \\
\text { On-site Evaluation [2.4.2] }\end{array}$ & Orientation meeting record \\
\hline 3.2 & $\begin{array}{l}\text { Conduct examination(s) of } \mathrm{M} \& \\
\text { A data repositories }\end{array}$ & $\begin{array}{l}\text { - Quality-audited Phase } 2 \text { artifact } \\
\text { evaluation results [2.3] } \\
\text { - Client M \& A repository }\end{array}$ & Intermediate Phase 2-3 artifact evaluation results \\
\hline 3.3 & Conduct interviews & $\begin{array}{l}\text { - Interview questions organized by } \\
\text { interviewee [2.4.2] } \\
\text { - Intermediate Phase 2-3 artifact evaluation } \\
\text { results [3.2] }\end{array}$ & Interview transcripts \\
\hline 4 & Report Results & & \\
\hline
\end{tabular}




\begin{tabular}{|c|c|c|c|}
\hline Sec. & Title & Information Needed & Products \\
\hline 4.1 & $\begin{array}{l}\text { Analyze on-site evaluation } \\
\text { results }\end{array}$ & $\begin{array}{l}\text { - Intermediate Phase 2-3 artifact evaluation } \\
\text { results [3.2] } \\
\text { - Interview transcripts [3.3] }\end{array}$ & Final MAID criteria evaluation results \\
\hline 4.2 & Derive key findings & $\begin{array}{l}\text { - } \quad \text { List of client SMEs [1.2] } \\
\text { - } \quad \text { Approved MAID plan [1.3.5] } \\
\text { - } \quad \text { Questionnaire results organized for } \\
\text { - } \quad \text { reporting purposes [2.4] } \\
\text { Final MAID criteria evaluation results [4.1] }\end{array}$ & Final MAID criteria evaluation findings \\
\hline 4.3 & Deliver key findings & Final MAID criteria evaluation findings [4.2] & Delivered MAID results \\
\hline 4.4 & Plan next steps & Delivered MAID results [4.3] & Action plan \\
\hline
\end{tabular}

11 Note that the Approved MAID plan includes List of MAID objectives [1.1.1], MAID scope statement [1.1.3], List of outputs with descriptions that will be developed based on the results of the MAID [1.3.4]. 


\section{Appendix B: Example Agenda for On-Site Evaluation}

This is an example agenda for the first day of Phase 3: On-Site Evaluation. Note that this is only an example, and the topic list and times assigned to each topic will depend on the chosen scope of the MAID.

\begin{tabular}{|c|c|c|c|}
\hline Start & End & Time & Topic \\
\hline 8:00 AM & 9:00 & $1: 00$ & Kick-off meeting \\
\hline 9:00 & $9: 30$ & $0: 30$ & Break \& set up for interviews \\
\hline $9: 30$ & $10: 15$ & $0: 45$ & Interview - Data consumers \\
\hline $10: 15$ & $10: 30$ & $0: 15$ & Interview review \& prep for next interview \\
\hline $10: 30$ & $10: 40$ & $0: 10$ & MAID Team Break \\
\hline $10: 30$ & $11: 15$ & $0: 45$ & Interview - Data producers \\
\hline $11: 15$ & $11: 30$ & $0: 15$ & Interview review \& prep for next interview \\
\hline $11: 30$ & 12:15 PM & $0: 45$ & Interview - Data storage \\
\hline $12: 15$ & $12: 45$ & $0: 30$ & Examination - Data storage \\
\hline $12: 45$ & $1: 00$ & $0: 15$ & Interview review \& prep for next interview \\
\hline $1: 00$ & $2: 00$ & $1: 00$ & Lunch \& Prep for afternoon \\
\hline $2: 00$ & $2: 45$ & $0: 45$ & Interview - Data Analysts \\
\hline $2: 45$ & 3:00 & $0: 15$ & Interview review \& prep for next interview \\
\hline 3:00 & $3: 10$ & $0: 10$ & MAID Team Break \\
\hline $3: 10$ & $3: 55$ & $0: 45$ & Interview - M\&A Info Designers and Presenters \\
\hline $3: 55$ & $4: 10$ & $0: 15$ & Interview review \& prep for next interview \\
\hline $4: 10$ & $5: 00$ & $0: 50$ & MAID Team -Day 1 Wrap-up \\
\hline
\end{tabular}


70 | CMU/SEI-2010-TR-035 


\section{Appendix C: Example Questions for Self-Administered Questionnaire}

The following are some example questions that might be included in a self-administered survey to obtain stakeholder feedback.

The results of the survey can be combined with other MAID results from the artifact evaluation and the interviews to provide a well-rounded picture of the health of $M \& A$ practices within the organization undergoing a MAID evaluation.

1. Which of the following best describes the role you play in your organization (Please select one.)

$\square$ Executive or senior management

$\square$ Middle manager

$\square$ Project manager

$\square$ Project engineer or other technical staff

$\square$ Process or quality engineer

$\square$ Measurement specialist

$\square$ Other (describe briefly)

2. Please select the response that best describes your involvement with measurement. (Select a single response.)

I am a provider of measurement-based information

$\square$ I am a user (consumer) of measurement-based information

$\square \quad$ I am both a provider and user (consumer) of measurement-based information

$\square$ Other (please specify) 
3. Generally speaking, I believe that using measurement-based data helps my team to perform better than without using it.
Strongly Agree
Agree
$\square$ Somewhat Agree
$\square$ Not sure
$\square$ Somewhat Disagree
$\square$ Disagree
$\square$ Strongly Disagree
$\square \mathrm{N} / \mathrm{A}$

4. The definitions of measures that are used in my organization are commonly understood and consistent.

$\square$ Strongly Agree

Agree

$\square$ Somewhat Agree

$\square$ Not sure

$\square$ Somewhat Disagree

$\square$ Disagree

$\square$ Strongly Disagree

$\square \mathrm{N} / \mathrm{A}$

5. Select each method that you use to identify, collect, and analyze your measurement data. (You may select more than one response.)

I do not use a defined method.

$\square$ Goal-Driven Software Measurement method

$\square$ Practical Systems and Software (PSM) method

$\square$ GQM (Goal-Question-Metric)

$\square$ CMMI Measurement and Analysis Process Area

Personal Software Process (PSP) \& Team Software Process (TSP)

$\square \quad$ ISO 15939 (Information Technology - Software Engineering - Software Measurement Process

$\square$ Other (please specify) 
Please select the response that best describes you or your team. (Select a single response for each numbered item.)

6. There exist measurable criteria for the products and services to which I contribute.

Frequently Occasionally Rarely Never I don't know N/A

7. I use measurement to understand the quality of the products and/or services that I work on.

Frequently Occasionally Rarely Never I don't know N/A

8. My team follows a documented process for collecting measurement data.

Frequently Occasionally Rarely Never I don't know N/A

9. My team follows a documented process for reporting measurement data to management.

Frequently Occasionally Rarely Never I don't know N/A


In the following question the term "threshold" indicates a target or boundary that when exceeded is evidence that a risk or problem exists.

10. Corrective action is taken when measurement data indicate that a threshold has been exceeded. (Select a single response.)

Frequently Occasionally Rarely Never I don't know N/A

11. I understand the purposes for the data I collect or report. (Select a single response.)

$\begin{array}{lllll}\text { Frequently Occasionally Narely Never I don't know N } & \text { Rar }\end{array}$

12. How often are qualified, well-prepared people available to work on measurement and analysis in your organization when you need them (i.e., people with sufficient measurement-related knowledge, competence, or statistical sophistication). (Please select one.)

Almost always ( $\geq 80 \%)$

Frequently (between $60 \%$ and $80 \%$ )

About half the time (between $40 \%$ and $60 \%$ )

Occasionally (between $20 \%$ and $40 \%$ )

Rarely $(\leq 20 \%)$ 
13. How would you best characterize the measurement and analysis training that is available in the organization? (Please select one.)

$\square$ Excellent

$\square$ Good

$\square$ Adequate

$\square$ Fair

$\square$ Poor 
76 | CMU/SEI-2010-TR-035 


\section{Appendix D: Guidance for Conducting Interviews}

Overview

Parts of the interview
This appendix provides guidance for conducting interviews during Phase 3: Conducting On-Site Evaluation.

The interview meeting is a three-part process, as described in the table below.

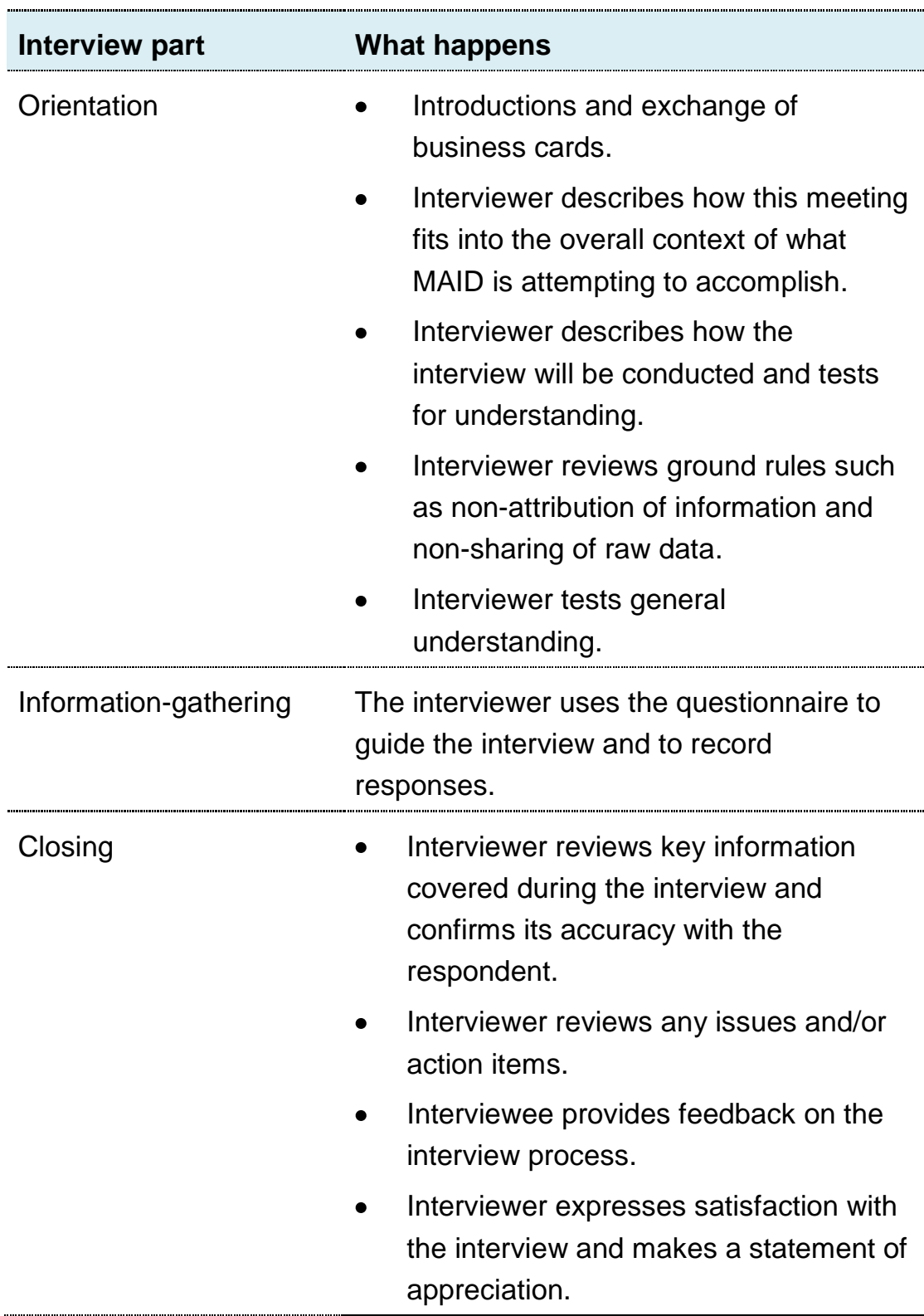


Recommendations for orientation

Interviewer guidelines
Some recommendations for conducting the interview orientation are provide below.

- Obtain respondent contact information and record it (if you do not have it already).

- If you anticipate that a respondent may not understand the context for the interview and how it fits with the MAID evaluation and the $M \& A$ improvement effort, you should be prepared for a 5-10 minute presentation to cover these topics. Use presentation slides to convey your story.

- Ensure that the respondent understands the objectives of the interview and how the information from the interview will be used.

- Explain the ground rules for the interview and suggest response guidelines. Remind the respondent that the information will be used by the MAID team and responses will not be shared in a way to disclose the identity of the individual who provides the information.

- Explain what will happen during the course of the interview.

- Invite the respondent to ask questions.

The interviewer needs to be prepared for the primary task: being an effective listener. Some common pitfalls that can threaten an effective interview include

- $\quad$ permitting personal prejudices or deep-seated convictions to overwhelm or impair comprehension or interpretation

- interjecting interviewer comments that can bias the response

- $\quad$ preparing to answer questions before fully understanding them

- listening only to what is easy to understand

- allowing emotionally-laden words to interfere with listening

- thinking you already know what the respondent would say to a question based on the respondent's prior responses [Barker 1971, pp. 61-65] 


\section{Asking the questions}

- Use the questionnaire carefully, but informally.

The questionnaire includes topic areas that address important issues; however, if interviewers focus too much on the instrument and read the questions, they may appear unprofessional and disinterested.

Interviewer should memorize the first few questions so they refer to the instrument only occasionally, using eye contact and a confident manner to set the tone for the interview and help establish rapport with the respondent.

- Ask every question.

Sometimes interviewers will be tempted to omit a question because they think they already know what the respondent will say. In those cases, where the interviewer feels that a question has already been addressed (through some tangential aspect of a different question), they should still repeat the written question saying something like "I know you may have already mentioned this, but ..." 


\section{Obtaining adequate \\ responses}

When the respondent gives a brief, cursory answer, the interviewer needs to elicit a more thoughtful, thorough response. There may be times when the response is vague and where more clarity is needed.

Here are a number of probing techniques that can be used:

- The silent probe

The most effective way to encourage someone to elaborate is to do nothing at all-just pause and wait. This is referred to as the silent probe. It works (at least in some cultures) because the respondent is uncomfortable with pauses or silence. It suggests to respondents that the interviewer is waiting, listening for what they will say next.

- Overt encouragement

At times, interviewers can encourage the respondent directly. They should try to do so in a way that does not imply approval or disapproval of what the respondent said (that could bias their subsequent results). Overt encouragement could be as simple as saying "uh-huh" or "okay" after the respondent completes a thought.

- Elaboration

Interviewers can encourage more information by asking for elaboration. For instance, it is appropriate to ask questions such as, "Would you like to elaborate on that?" or "Is there anything else you would like to add?"

- Ask for clarification

Sometimes, interviewers can elicit greater detail by asking the respondent to clarify something that was said earlier by saying something such as, "A minute ago you were talking about the experience you had while collecting defect data. Could you tell me more about that?"

- Repetition

Interviewers sometimes need to verify the correctness of their understanding of the respondent's comments. For instance, suppose the respondent just described a situation that was problematic for him or her. The interviewer might say "What I'm hearing you say is that you found that experience to be especially problematic in your organization" and then pause. The respondent is likely to say something like, "Well, yes, and it affected not only our organization, but it had an impact on our relationship with ...." 
Example:

Follow-up questions

The session transcript
The questions listed in the questionnaire are a guide for the interview, but it will often be necessary to follow up these questions with probing or clarifying questions.

Skilled interviewers use several types of questions to draw out the information they need. Some examples of each are provided below.

\begin{tabular}{ll}
\hline Question type & Example \\
\hline Probing & $\bullet \quad$ "Can you give me a specific example of what \\
& $\begin{array}{l}\text { you mean?" } \\
\text { "How often do you report information to the } \\
\end{array}$ \\
\hline Clarifying & Chief Engineer?" \\
& "Do I understand correctly that what you're \\
& saying is ...?" \\
& "When you say that there are problems with \\
& communication, what do you mean?"
\end{tabular}

The session transcript is essential to the analysis of the interview results.

Although you may have the capability to record a respondent in audio or video, most interview methodologists do not think that mechanized recording is a good idea. Respondents are often uncomfortable when they know their remarks will be recorded word-for-word. They may strain to say things only in a socially acceptable way. Although you would get a more detailed and accurate record, it is likely to be unduly distorted by the process of obtaining it. In general, personal interviews are still best when recorded by the interviewer using pen and paper.

[Trochim 2001, p. 130] 


\section{Guidelines: \\ Recording \\ responses}

\section{Concluding the} interview
- Record responses immediately.

The scribe should record responses as they are being stated. This conveys the idea that they are interested enough in what the respondent is saying to write it down. The scribe does not have to write down every single word, but certain key phrases or quotes should be recorded verbatim. A system should be implemented for distinguishing what the respondent says verbatim from what the interviewers are characterizing.

- Include all probes.

The transcript should indicate every single probe that is used. Develop shorthand for different standard probes. Use a clear method for writing them (for example, place probes in the left margin). Use abbreviations where possible; abbreviations will help interviewers capture more of the discussion. Develop a standardized system (e.g., R=respondent; DK=don't know). If the interviewer creates an abbreviation on the fly, they should record its origin. For instance, if you as an interviewer decides to abbreviate project management indicators with PMI, make a notation in the right margin saying $\mathrm{PMI}=$ project management indicator.

The actions listed below should be taken to bring the interview to closure.

- The interviewer should review any actions and issues that were identified during the meeting.

- Immediately after leaving, the interviewer should write down notes about how the interview went. Sometimes interviewers will have observations about the interview that they did not want to write down while they were with the respondent. Immediately after the interview, go over the interview notes and make any other comments and observations, but be sure to distinguish these from notes made during the interview (by using a different color pen, for instance). 
Do's and Don'ts for the interviewer
A number of guidelines for conducting the interviews have been presented in this section. The following is a summary list of important "do's" and "don'ts".

Do the following:

- Focus on the primary objective of the meeting during information gathering - which is to collect information.

- Ask every question. This will require discipline on the part of the interviewer who will need to manage time carefully. Keep track of the time so that all questions are covered during the interview meeting. (You may have to intervene in some cases to keep the interview from stalling on any single topic.)

- Record responses on the interview form. Have a prepared strategy for doing this. Do not rely on an audio recording device. See the section titled, "Recording the responses" on page 82 of this document.

Do not do the following:

- Allow personal stories to take up valuable time. The purpose is to obtain information from the interviewee.

- Diverge too far from the questionnaire. Opportunities abound to discuss interesting but unrelated matters, but there is a pressing need for focus given the time limits.

- Allow your personal interests to become part of the discussion. It is important not to cue the respondent with topics that they would not identify on their own.

\section{Immediately after the interview}

Immediately after the interview has been adjourned, the interviewer should review the interview transcript and annotate it as needed to clarify any vague statements that may be difficult to interpret at a later time (e.g., abbreviations, incomplete thoughts). These annotations should be labeled as such to distinguish them from the information that was recorded during the interview. 
84 | CMU/SEI-2010-TR-035 


\section{References}

URLs are valid as of the publication date of this document.

\section{[Barker 1971]}

Barker, L. Listening Behavior. Prentice-Hall, Inc. 1971.

\section{[Kasunic 2005]}

Kasunic, Mark. Designing an Effective Survey (CMU/SEI-2005-HB-004). Software

Engineering Institute, Carnegie Mellon University, 2005.

http://www.sei.cmu.edu/library/abstracts/reports/05hb004.cfm

\section{[Kasunic 2008]}

Kasunic, Mark. Can You Trust Your Data? Establishing the Need for a Measurement and Analysis Infrastructure Diagnostic (CMU/SEI-2008-TN-028). Software Engineering Institute, Carnegie Mellon University, 2008.

http://www.sei.cmu.edu/library/abstracts/reports/08tn028.cfm

\section{[SEMA 2009]}

CMMI Product Team. Measurement and Analysis Infrastructure Diagnostic (MAID) Evaluation Criteria, Version 1.0. (CMU/SEI-2009-TR-022). Software Engineering Institute, Carnegie Mellon University, 2009.

http://www.sei.cmu.edu/library/abstracts/reports/09tr022.cfm

\section{[Trochim 2001]}

Trochim, William M.K. The Research Methods Knowledge Base, Second Edition. Cornell University, 2001. 
86 | CMU/SEI-2010-TR-035 


\section{REPORT DOCUMENTATION PAGE}

Form Approved

Public reporting burden for this collection of information is estimated to average 1 hour per response, including the time for reviewing instructions, searching existing data sources, gathering and maintaining the data needed, and completing and reviewing the collection of information. Send comments

regarding this burden estimate or any other aspect of this collection of information, including suggestions for reducing this burden, to Washington

Headquarters Services, Directorate for information Operations and Reports, 1215 Jefferson Davis Highway, Suite 1204, Arlington, VA 22202-4302, and to the Office of Management and Budget, Paperwork Reduction Project (0704-0188), Washington, DC 20503.

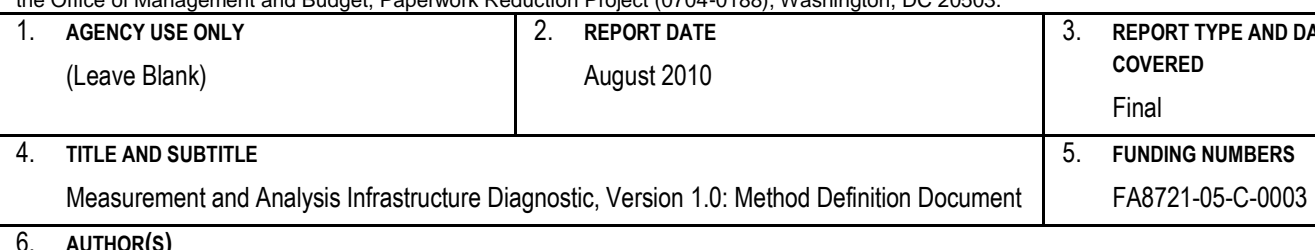

6. AUTHOR(s)

Mark Kasunic

7. PERFORMING ORGANIZATION NAME(S) AND ADDRESS(ES)

Software Engineering Institute

Carnegie Mellon University

8. PERFORMING ORGANIZATION

REPORT NUMBER

Pittsburgh, PA 15213

9. SPONSORING/MONITORING AGENCY NAME(S) AND ADDRESS(ES)

HQ ESC/XPK

5 Eglin Street

Hanscom AFB, MA 01731-2116

CMU/SEI-2010-TR-035

11. SUPPLEMENTARY NOTES

\begin{tabular}{l|l}
\hline 12A DISTRIBUTION/AVAILABILITY STATEMENT & 12B DISTRIBUTION CODE \\
Unclassified/Unlimited, DTIC, NTIS & \\
\hline
\end{tabular}

13. ABSTRACT (MAXIMUM 200 WORDS)

This document is a guidebook for conducting a Measurement and Analysis Infrastructure Diagnostic (MAID) evaluation. The MAID method is a criterion-based evaluation method that is used to assess the quality of an organization's data and the information generated from that data.

The method is organized into four phases: (1) Collaborative Planning, (2) Artifact Evaluation, (3) On-site Evaluation, and (4) Report Results. Using the MAID evaluation criteria as a guide, a MAID team systematically studies and evaluates an organization's measurement and analysis practices by examining the organization's data and observing how the data is manipulated during its lifecycle, from the collection of base measures to the information provided to decision makers.

The outcome of a MAID evaluation is a detailed report of an organization's strengths and weaknesses in measurement and analysis.

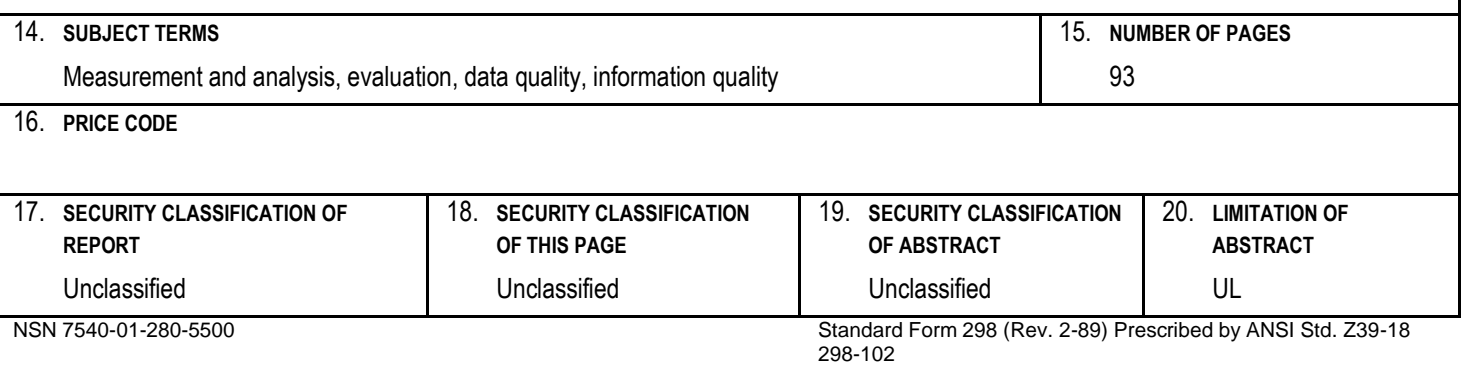

